\title{
Response of winter fine particulate matter concentrations to emission and meteorology changes in North China
}

\author{
Meng Gao ${ }^{1,2}$, Gregory R. Carmichael ${ }^{1,2}$, Pablo E. Saide ${ }^{2, a}$, Zifeng Lu $^{3}$, Man Yu ${ }^{1,2, b}$, David G. Streets ${ }^{3}$, and Zifa Wang ${ }^{4}$ \\ ${ }^{1}$ Department of Chemical and Biochemical Engineering, University of Iowa, Iowa City, IA, USA \\ ${ }^{2}$ Center for Global and Regional Environmental Research, University of Iowa, Iowa City, IA, USA \\ ${ }^{3}$ Energy Systems Division, Argonne National Laboratory, Argonne, IL, USA \\ ${ }^{4}$ State Key Laboratory of Atmospheric Boundary Layer Physics and Atmospheric Chemistry, \\ Institute of Atmospheric Physics, Chinese Academy of Sciences, Beijing, China \\ ${ }^{a}$ now at: Atmospheric Chemistry observations and Modeling (ACOM) lab, National Center for Atmospheric Research \\ (NCAR), Boulder, CO, USA \\ ${ }^{b}$ now at: Mathematics and Computer Science Division, Argonne National Laboratory, Argonne, IL, USA \\ Correspondence to: Meng Gao (meng-gao@uiowa.edu) and Gregory R. Carmichael (gcarmich@engineering.uiowa.edu)
}

Received: 18 May 2016 - Published in Atmos. Chem. Phys. Discuss.: 8 June 2016

Revised: 12 September 2016 - Accepted: 13 September 2016 - Published: 23 September 2016

\begin{abstract}
The winter haze is a growing problem in North China, but the causes are not well understood. The chemistry version of the Weather Research and Forecasting model (WRF-Chem) was applied in North China to examine how $\mathrm{PM}_{2.5}$ concentrations change in response to changes in emissions (sulfur dioxide $\left(\mathrm{SO}_{2}\right)$, black carbon $(\mathrm{BC})$, organic carbon $(\mathrm{OC})$, ammonia $\left(\mathrm{NH}_{3}\right)$, and nitrogen oxides $\left.\left(\mathrm{NO}_{x}\right)\right)$, as well as meteorology (temperature, relative humidity $(\mathrm{RH})$, and wind speeds) changes in winter. From 1960 to 2010, the dramatic changes in emissions lead to $+260 \%$ increases in sulfate, $+320 \%$ increases in nitrate, $+300 \%$ increases in ammonium, $+160 \%$ increases in $\mathrm{BC}$, and $+50 \%$ increases in OC. The responses of $\mathrm{PM}_{2.5}$ to individual emission species indicate that the simultaneous increases in $\mathrm{SO}_{2}, \mathrm{NH}_{3}$, and $\mathrm{NO}_{x}$ emissions dominated the increases in $\mathrm{PM}_{2.5}$ concentrations. $\mathrm{PM}_{2.5}$ shows more notable increases in response to changes in $\mathrm{SO}_{2}$ and $\mathrm{NH}_{3}$ as compared to increases in response to changes in $\mathrm{NO}_{x}$ emissions. In addition, $\mathrm{OC}$ also accounts for a large fraction in $\mathrm{PM}_{2.5}$ changes. These results provide some implications for haze pollution control. The responses of $\mathrm{PM}_{2.5}$ concentrations to temperature increases are dominated by changes in wind fields and mixing heights. $\mathrm{PM}_{2.5}$ shows relatively smaller changes in response to temperature increases and RH decreases compared to changes in response to changes in wind speed and aerosol feedbacks. From 1960 to 2010, aerosol feedbacks have been
\end{abstract}

significantly enhanced due to higher aerosol loadings. The discussions in this study indicate that dramatic changes in emissions are the main cause of increasing haze events in North China, and long-term trends in atmospheric circulations may be another important cause since $\mathrm{PM}_{2.5}$ is shown to be substantially affected by wind speed and aerosol feedbacks. More studies are necessary to get a better understanding of the aerosol-circulation interactions.

\section{Introduction}

$\mathrm{PM}_{2.5}$ (particulate matter with diameter equal to or less than $2.5 \mu \mathrm{m}$ ) is a main air pollution concern due to its adverse effects on public health (Gao et al., 2015; Pope et al., 2009). Pope et al. (2009) estimated that a decrease of $10 \mu \mathrm{g} \mathrm{PM}_{2.5}$ is related to about 0.6-year mean life expectancy increase. $\mathrm{PM}_{2.5}$ is also associated with visibility reduction and regional climate (Cheung et al., 2005). Many cities in North China are experiencing severe haze pollution with exceedingly high $\mathrm{PM}_{2.5}$ concentrations. In January 2010, a regional haze occurred in North China and maximum hourly $\mathrm{PM}_{2.5}$ concentration in Tianjin was over $400 \mu \mathrm{g} \mathrm{m}^{-3}$ (Zhao et al., 2013). In January 2013, another unprecedented haze event happened, and the daily $\mathrm{PM}_{2.5}$ concentrations in some areas of Beijing and Shijiazhuang reached over $500 \mu \mathrm{g} \mathrm{m}^{-3}$ 
(L. T. Wang et al., 2014), and instantaneous $\mathrm{PM}_{2.5}$ concentration at some urban measurement sites was over $1000 \mu \mathrm{g} \mathrm{m}^{-3}$ (Zheng et al., 2015).

It is well known that PM levels are strongly influenced by emissions and meteorological conditions (Steiner et al., 2006). The PM in the atmosphere can be directly emitted from sources like wildfires, combustion, windblown dust, and sea salt or formed from emitted gases through secondary aerosol formation mechanisms. Meteorology affects PM levels via changing emissions, chemical reactions, transport and deposition processes (Mu and Liao, 2014). For example, increasing wildfire emission in North America is mainly caused by warmer temperatures and precipitation changes (Dawson et al., 2014), and increased temperature leads to higher biogenic emissions, which are important precursors of secondary organic aerosols (SOAs) (Dawson et al., 2014; Heald et al., 2008; Jacob and Winner, 2009). Increasing temperature also increases sulfate concentration due to the temperature dependence of $\mathrm{SO}_{2}$ oxidation and resulting higher $\mathrm{SO}_{2}$ oxidation rates (Aw and Kleeman, 2003; Dawson et al., 2007), and semivolatile aerosols may decrease due to evaporation under higher temperature (Sheehan and Bowman, 2001; Dawson et al., 2007; Tsigaridis and Kanakidou, 2007). Higher relative humidity $(\mathrm{RH})$ favors the formation of nitrate and increasing precipitation decreases all PM species via wet scavenging (Dawson et al., 2007; Tai et al., 2010). Furthermore, increasing clouds promote in-cloud sulfate production (Tai et al., 2010), and changes in wind speed and mixing height determine the dilution of primary and secondary PM (Jiménez-Guerrero et al., 2012; Megaritis et al., 2014; Pay et al., 2012).

With rapid economic and industrial developments, emissions in China have grown during the past years. It is estimated that $\mathrm{NO}_{x}$ emissions in China increased by $70 \%$ from 1995 to 2004 (Zhang et al., 2007), black carbon (BC) by $\sim 50 \%$ from 2000 to 2010 (Lu et al., 2011), organic carbon (OC) by $\sim 30 \%$ from 2000 to 2010 (Lu et al., 2011), and $\mathrm{SO}_{2}$ by $\sim 60 \%$ from 2000 to 2006 (Lu et al., 2011). Apart from emission changes, it was observed that the winter is warming up in China, especially in the northern part (Guo et al., 2013; Hu, 2003; Ren et al., 2012). In addition, wind speed in North China has lowered (Shi et al., 2015; Wang et al., 2004) and RH has decreased throughout China (Song et al., 2012; Wang et al., 2004).

Many studies have investigated the impacts of emission changes on aerosol formation (Aksoyoglu et al., 2011; Andreani-Aksoyoglu et al., 2008; Megaritis et al., 2013; Tsimpidi et al., 2007, 2008) and the effects of climate/meteorology changes on $\mathrm{PM}_{2.5}$ concentrations (Dawson et al., 2007; Megaritis et al., 2013, 2014; Tagaris et al., 2007; Tai et al., 2012a, b) in Europe and in the United States. The haze pollution is growing in China, especially in North China, but the causes of the growth are not well understood. For haze pollution in China, it has been reported that aerosol feedbacks that change radiation and temperature can worsen pollution (Gao et al., 2016; Petäjä et al., 2016; Xing et al., 2015; B. Zhang et al., 2015). In addition, the connections between haze and meteorological conditions have been established in many previous studies (Fu et al., 2014; Jia et al., 2015; Leng et al., 2016; C. Li et al., 2016; Wang and Chen, 2016; Yang et al., 2016; X. Y. Zhang et al., 2015; Zhang et al., 2016). However, the role of the large emission changes during the last 4 to 5 decades and the observed meteorology changes in North China is not known.

The main objective of this study is to investigate the responses of $\mathrm{PM}_{2.5}$ and its major species to changes in emissions, including $\mathrm{SO}_{2}, \mathrm{BC}, \mathrm{OC}, \mathrm{NO}_{x}$, and $\mathrm{NH}_{3}$, and temperature, $\mathrm{RH}$, and wind speed in North China region. Winter haze in North China has a large contribution from secondary inorganic aerosols, and secondary inorganic aerosols are influenced by emissions, temperature, and RH. The models used in previous studies of emissions and meteorology perturbations referenced above are all offline models, which are not capable of considering the feedbacks of changing meteorology on other meteorological variables and the impacts of aerosols on meteorology. However, as pointed by Gao et al. (2016) and J. Wang et al. (2014), aerosol feedbacks should not be neglected when modeling aerosols in China. In this study, we consider aerosol feedbacks by using the fully online-coupled WRF-Chem model.

This paper is organized as follows. First, the WRF-Chem model, model settings, and domain settings are briefly described and, in the next section, emission changes from 1960 to 2010 and accordingly $\mathrm{PM}_{2.5}$ changes are discussed. After that, the responses of $\mathrm{PM}_{2.5}$ to changes in each emission species are analyzed. At last, the impacts of temperature, $\mathrm{RH}$, and wind speed changes on $\mathrm{PM}_{2.5}$ are analyzed and discussed.

\section{Methodology}

\subsection{WRF-Chem model}

The WRF-Chem model is the chemistry version of the Weather Research and Forecasting model, which is fully coupled online and allows gas and aerosol simulations at the same time as meteorology simulations. The gas-phase mechanism used in this study is the Carbon Bond Mechanism version $\mathrm{Z}$ (CBMZ), which includes 67 species and 164 reactions (Zaveri and Peters, 1999; Zaveri et al., 2008). The gas-particle partitioning module used is the MOSAIC module, which considers all important aerosol components, such as sulfate, nitrate, ammonium, BC, and $\mathrm{OC}$ (Zaveri et al., 2008). The version of MOSAIC with eight size bins was used and the aerosol sizes ranged from 0.039 to $10 \mu \mathrm{m}$. CBMZMOSAIC has been proven to be capable of simulating air quality in many previous studies all over the world. Furthermore, the CBMZ-MOSAIC configuration in WRF-Chem enables us to include aerosol feedbacks with the meteorol- 
ogy in winter haze in a comprehensive manner. The current implementation does not include the SOA formation, and this limitation is discussed later in the paper. Windblown dust was modeled online using the Air Force Weather Agency (AFWA) scheme. Two nested domains with 81 and $27 \mathrm{~km}$ horizontal grid resolutions from outer to innermost and 27 vertical grids were used (Fig. S1 in the Supplement). Analysis nudging of meteorology variables was used for the outer domain. In meteorological perturbation cases, the analysis nudging in outer domain includes perturbations in meteorological variables. The model physics configurations generally follow the settings in Gao et al. (2016). Inputs into the model include meteorological boundary and initial conditions (BCs and ICs) from NCEP FNL $1^{\circ} \times 1^{\circ}$ data and chemical boundary and initial conditions from MOZART model simulations (Emmons et al., 2010). Chemical BCs and ICs are not changing along with the sensitivity simulations, but the studied domain (innermost domain) takes boundary conditions from outer main, where emissions are perturbed. The anthropogenic emission inventory used is the MACCity (MACC/CityZEN EU projects) emissions dataset, which provides monthly $\mathrm{CO}, \mathrm{NO}_{x}, \mathrm{SO}_{2}$, volatile organic compounds (VOCs), $\mathrm{BC}, \mathrm{OC}$, and $\mathrm{NH}_{3}$ emissions from different sectors for years between 1960 and 2020 (Granier et al., 2011). We compared the MACCity emission inventory for 2010 (Granier et al., 2011) with the MIX emission inventory for 2010 ( $\mathrm{Li}$ et al., 2015) in the China region, and the magnitudes of emissions in China from these two datasets are very close. For example, the $\mathrm{SO}_{2}$ emissions in China in 2010 were estimated to be $28663 \mathrm{Gg}$ in the MIX emission inventory and were $26876.3 \mathrm{Gg}$ in the MACCity emission inventory. Simulations for evaluating roles of emission changes were conducted using emissions for year 1960 and year 2010. We assigned emissions to the first six layers from surface based on sectors. For example, emissions from large point sources (such as chimneys) were assigned to higher layers. Biogenic emissions were estimated online using the MEGAN model (Guenther et al., 2006). The simulation period was January 2010 and 5 days in previous month were modeled as spinup to overcome the influences of initial conditions.

\subsection{Sensitivity experiments}

We explored the sensitivities of $\mathrm{PM}_{2.5}$ concentrations during the month of January 2010 to changes in emissions and meteorology features through a series of simulations using 1960 and 2010 emission baselines. Specifically, the influences of emission changes of $\mathrm{SO}_{2}, \mathrm{BC}, \mathrm{OC}, \mathrm{NH}_{3}$, and $\mathrm{NO}_{x}$ as well as meteorology (temperature, $\mathrm{RH}$, and wind speeds) changes on $\mathrm{PM}_{2.5}$ and its major species were evaluated using a series of simulations. They are listed and explained in Table 1. All base simulations use meteorology of January 2010. CTL case uses emissions for year 1960 and EMI2010 case uses emissions for year 2010. $\mathrm{SO}_{2}, \mathrm{NH}_{3}$, and $\mathrm{NO}_{x}$ emissions were perturbed separately from 1960 to 2010 (i.g., $\mathrm{SO}_{2}-2010, \mathrm{NH}_{3}-2010$, and $\mathrm{NO}_{x}-2010$ cases). In the CTL_NF and EMI2010_NF cases, aerosol-radiation interactions are excluded based on emissions for years 1960 and 2010. It was pointed out that surface air temperature in North China increased at the rate of $0.36^{\circ} \mathrm{C}$ per decade (Guo et al., 2013), the linear trend coefficient of RH anomaly in North China is about $-0.60 \%$ per decade (Wang et al., 2004), and national mean wind speed decreased $16 \%$ in the last 50 years (Wang et al., 2004). To estimate the impacts of changes in temperature, $\mathrm{RH}$, and wind speed that happened in the past several decades, we decreased temperature by $2^{\circ}$, increased $\mathrm{RH}$ by $10 \%$, and increased wind speeds by $20 \%$, to reflect conditions of early decades (CTL_T2, CTL_RH10, CTL_WS20 EMI2010_T2, EMI2010_RH10, and EMI2010_WS20 cases). These were conducted by perturbing the initial and boundary conditions of these individual meteorological variables.

At different vertical heights, emission and meteorological variables were uniformly perturbed. The changes of $\mathrm{PM}_{2.5}$ and its major components due to perturbations in emissions and meteorology are analyzed for the North China region. The North China region is defined using the innermost domain (shown in Fig. S1) and the statistics of changes are calculated within this domain for the month of January 2010.

\subsection{Model verification}

The WRF-Chem model performance has been evaluated using multiple observations, including surface meteorological, chemical, and optical data and satellite data in Gao et al. (2016). The model was shown to capture the variations of surface temperature and RH, while wind speed was slightly overestimated (Gao et al., 2016), which has been reported as a common problem of current WRF-Chem model under low wind speed conditions. The root mean square error (RMSE) of temperature were all less than $3.2 \mathrm{~K}$ and RMSEs of RH varied from 6.4 to $11.1 \%$. The RMSE of wind speeds were below the proposed criteria $\left(2 \mathrm{~m} \mathrm{~s}^{-1}\right)$ (Emery et al., 2001) at the Beijing, Tianjin, and Baoding stations but larger than that criteria at the Chengde station. The time series of simulated surface $\mathrm{PM}_{2.5}, \mathrm{NO}_{2}$, and $\mathrm{SO}_{2}$ showed good agreement with observations as did simulated aerosol optical depth (AOD) (Gao et al., 2016). Mean fractional bias ranged from -21.8 to $0.4 \%$ and mean fractional error ranged from 26.3 to $50.7 \%$ when comparing against $\mathrm{PM}_{2.5}$ observations (Gao et al., 2016). In addition, the comparison between model results and satellite found that the vertical distribution of aerosol and horizontal distribution were captured well by the model (Gao et al., 2016). Compared with observed $\mathrm{PM}_{2.5}$ composition, sulfate and $\mathrm{OC}$ were underestimated and nitrate was overestimated by the model (Gao et al., 2016). The underestimation of sulfate may be due to underestimation of $\mathrm{SO}_{2}$ gas-phase oxidation, errors in aqueous-phase chemistry, and/or missing heterogeneous sulfate formation (Gao et al., 2016). 
Table 1. Simulation cases and descriptions.

\begin{tabular}{|c|c|}
\hline Cases & Descriptions \\
\hline CTL & $\begin{array}{l}\text { Base case: anthropogenic emissions are from MACCity dataset for year 1960; meteorological conditions are } \\
\text { for January } 2010\end{array}$ \\
\hline EMI2010 & Anthropogenic emissions are from MACCity dataset for year 2010 \\
\hline $\mathrm{SO}_{2}-2010$ & Same as CTL case except $\mathrm{SO}_{2}$ emissions are for year 2010 \\
\hline $\mathrm{NH}_{3}-2010$ & Same as CTL case except $\mathrm{NH}_{3}$ emissions are for year 2010 \\
\hline $\mathrm{NO}_{x}-2010$ & Same as CTL case except $\mathrm{NO}_{x}$ emissions are for year 2010 \\
\hline CTL_T2 & Same as CTL case except temperature BCs and ICs are decreased by $2 \mathrm{~K}$ \\
\hline CTL_RH10 & Same as CTL case except RH BCs and ICs are increased by $10 \%$ \\
\hline CTL_WS20 & Same as CTL case except wind speed BCs and ICs are increased by $20 \%$ \\
\hline CTL_NF & Same as CTL case except aerosol-radiation interactions are excluded \\
\hline EMI2010_T2 & Same as EMI 2010 case except temperature BCs and ICs are decreased by $2 \mathrm{~K}$ \\
\hline EMI2010_RH10 & Same as EMI2010 case except RH BCs and ICs are increased by $10 \%$ \\
\hline EMI2010_WS20 & Same as EMI2010 case except wind speed BCs and ICs are increased by $20 \%$ \\
\hline EMI2010_NF & Same as EMI2010 case except aerosol-radiation interactions are excluded \\
\hline BCs_1960-2010 & Innermost domain emissions fixed in 1960 and the outer domain emissions changed from 1960 to 2010 \\
\hline EMI_2030 & perturbed $\mathrm{SO}_{2}, \mathrm{NO}_{x}$, and $\mathrm{NH}_{3}$ emissions by $-26,19$, and $14 \%$ \\
\hline
\end{tabular}

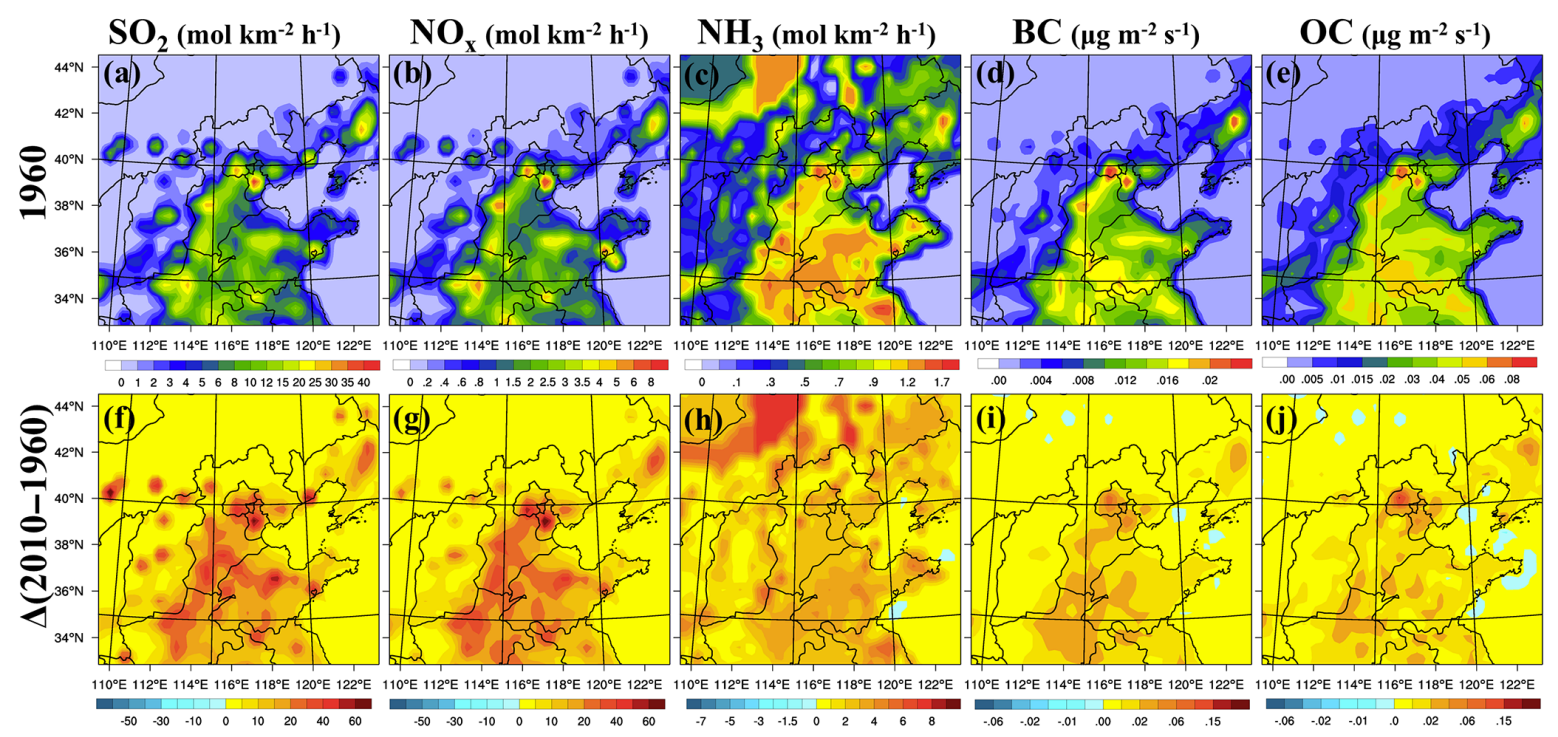

Figure 1. $\mathrm{SO}_{2}, \mathrm{NO}_{x}, \mathrm{NH}_{3}, \mathrm{BC}$, and $\mathrm{OC}$ emissions for year 1960 (a-e) and their changes from 1960 to 2010 (f-j).

\section{Results and discussion}

\section{1 $\mathrm{PM}_{2.5}$ sensitivity to emission changes from 1960 to 2010}

The emission changes of $\mathrm{SO}_{2}, \mathrm{NO}_{x}, \mathrm{NH}_{3}, \mathrm{BC}$, and $\mathrm{OC}$ and resulting impacts on $\mathrm{PM}_{2.5}$ from 1960 to 2010 were examined based on the MACCity dataset for years 1960 and 2010. Figure 1a-e display $\mathrm{SO}_{2}, \mathrm{NO}_{x}, \mathrm{NH}_{3}, \mathrm{BC}$, and $\mathrm{OC}$ emissions for 1960 and Fig. 1f $-\mathrm{j}$ show the changes from 1960 to 2010. Populated regions of North China, such as urban Beijing, urban Tianjin, and urban Shijiazhuang, exhibit large emissions of $\mathrm{SO}_{2}, \mathrm{NO}_{x}, \mathrm{NH}_{3}, \mathrm{BC}$, and $\mathrm{OC}$ in 1960. However, $\mathrm{NH}_{3}$ emissions exhibit different spatial distribution pat- terns from $\mathrm{SO}_{2}, \mathrm{NO}_{x}, \mathrm{BC}$, and $\mathrm{OC}$ emissions because $\mathrm{NH}_{3}$ is mainly associated with agriculture while $\mathrm{SO}_{2}, \mathrm{NO}_{x}, \mathrm{BC}$, and $\mathrm{OC}$ are mainly related with industrial and residential activities. From 1960 to 2010, $\mathrm{SO}_{2}, \mathrm{NO}_{x}, \mathrm{NH}_{3}, \mathrm{BC}$, and $\mathrm{OC}$ increased over the entire North China domain and markedly increased in the Jing-Jin-Ji city cluster. In general, the domainaveraged $\mathrm{SO}_{2}$ emissions and $\mathrm{NO}_{x}$ emissions in North China increased by $\sim 220$ and $\sim 990 \%$ from 1960 to 2010, respectively. The domain-averaged $\mathrm{NH}_{3}$ emissions in North China increased by $\sim 390 \%$ from 1960 to 2010, but the most significant increases occurred not in the Jing-Jin-Ji city cluster but in Inner Mongolia. Unlike $\mathrm{NH}_{3}$ emissions, $\mathrm{BC}$ emissions increased the most in urban Beijing from 1960 to 2010. 
Table 2. Monthly domain mean concentrations of $\mathrm{PM}_{2.5}$ and its major components for year 1960, and domain maximum and mean concentrations for changes from 1960 to 2010 due to emission changes $\left(\mu \mathrm{g} \mathrm{m}^{-3}\right)$.

\begin{tabular}{llrrrrrr}
\hline Years & & $\mathrm{SO}_{4}^{2-}$ & $\mathrm{NO}_{3}^{-}$ & $\mathrm{NH}_{4}^{+}$ & $\mathrm{BC}$ & $\mathrm{OC}$ & $\mathrm{PM}_{2.5}$ \\
\hline 1960 & Domain mean & 1.9 & 0.8 & 0.8 & 1.5 & 4.6 & 19.2 \\
\hline \multirow{2}{*}{$1960-2010$} & Domain maximum & 18.9 & 7.8 & 6.8 & 9.9 & 11.1 & 45.0 \\
& Domain mean & $5.0(264.0 \%)$ & $2.6(322.5 \%)$ & $2.3(295.2 \%)$ & $2.3(156.6 \%)$ & $2.5(54.0 \%)$ & $14.7(76.4 \%)$ \\
\hline
\end{tabular}
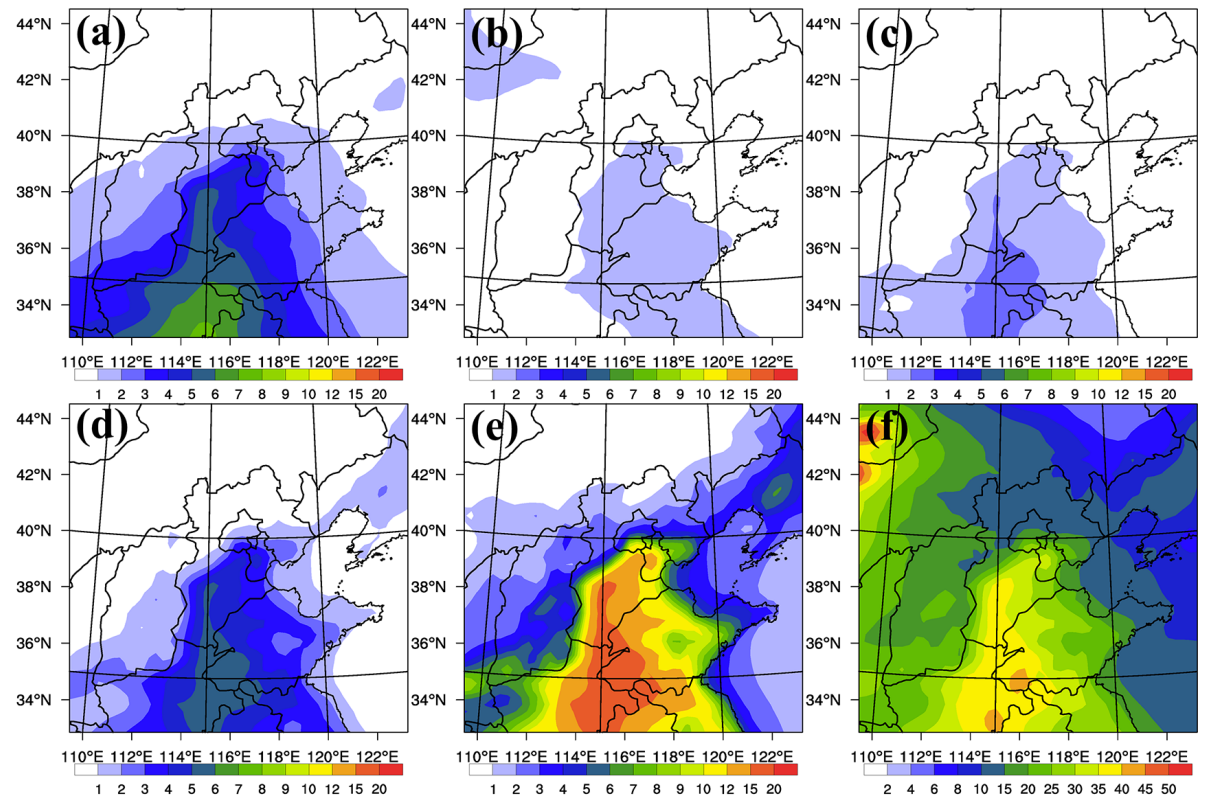

Figure 2. Predicted monthly mean sulfate (a), nitrate (b), ammonium (c), BC (d), OC (e), and $\mathrm{PM}_{2.5}$ (f) concentrations based on emissions for year 1960 .

This is because residential sources are the biggest contributor to $\mathrm{BC}$ in winter (K. Li et al., 2016) and the population in urban Beijing sharply increased with rapid urbanization. From 1960 to 2010, the mean BC emissions in North China increased by $\sim 154 \%$. Similar to BC emissions, OC emissions increased substantially in the center of Beijing, and the domain-averaged increasing ratio is about $54 \%$ from 1960 to 2010. The enhancements of $\mathrm{SO}_{2}, \mathrm{NO}_{x}, \mathrm{NH}_{3}, \mathrm{BC}$, and $\mathrm{OC}$ emissions in North China are expected to result in substantial increase in regional $\mathrm{PM}_{2.5}$ concentrations.

Figure 2 shows the simulated monthly mean concentrations of $\mathrm{PM}_{2.5}$ and its major components (sulfate, nitrate, ammonium, BC, and OC) based on emissions for year 1960. As listed in Table 2, the domain-averaged concentrations of sulfate, nitrate, ammonium, $\mathrm{BC}, \mathrm{OC}$, and $\mathrm{PM}_{2.5}$ are 1.9, 0.8, 0.8, $1.5,4.6$, and $19.2 \mu \mathrm{g} \mathrm{m}^{-3}$, respectively. For year $1960, \mathrm{PM}_{2.5}$ concentrations are mainly dominated by sulfate, OC, and natural dust (the difference between $\mathrm{PM}_{2.5}$ and the sum of sulfate, nitrate, ammonium, BC, OC). Figure 3 displays the changes of sulfate, nitrate, ammonium, $\mathrm{BC}, \mathrm{OC}$, and $\mathrm{PM}_{2.5}$ due to changes in $\mathrm{SO}_{2}, \mathrm{NO}_{x}, \mathrm{BC}$, and $\mathrm{OC}$ emissions from
1960 to 2010 . The predicted monthly mean concentrations of $\mathrm{PM}_{2.5}$ components and $\mathrm{PM}_{2.5}$ increase everywhere over the entire domain due to emission changes resulting from the rapid urbanization and industrialization from 1960 to 2010 (Fig. 3a-f). As listed in Table 2, the predicted monthly domain mean sulfate increases the largest $\left(5.0 \mu \mathrm{g} \mathrm{m}^{-3}\right)$, followed by nitrate $\left(2.6 \mu \mathrm{g} \mathrm{m}^{-3}\right)$ and OC $\left(2.5 \mu \mathrm{g} \mathrm{m}^{-3}\right)$.

From 1960 to 2010, the predicted BC increased by $\sim 157 \%$ and $\mathrm{OC}$ increased by $\sim 54 \%$ due to $154 \%$ increase in $\mathrm{BC}$ emissions and $54 \%$ increase in $\mathrm{OC}$ emissions. The nearly linear response of both $\mathrm{BC}$ and $\mathrm{OC}$ aerosols to their emissions is due to the omission of a SOA formation in the chosen CBMZ/MOSAIC mechanism. Thus, both of them were treated as primary aerosols in these simulations. Our previous analyses indicate that SOA contribution in this time period was small (Gao et al., 2016). The limitation of this omission is discussed later in this paper. The domain mean $\mathrm{PM}_{2.5}$ concentrations increased by $14.7 \mu \mathrm{g} \mathrm{m}^{-3}$ and the domain maximum increase is about $45 \mu \mathrm{g} \mathrm{m}^{-3}$ (Fig. $3 \mathrm{f}$ and Table 2). 
Table 3. Monthly domain mean changes of sulfate, nitrate, ammonium, and $\mathrm{PM}_{2.5}$ concentrations $\left(\mu \mathrm{g} \mathrm{m}^{-3}\right.$ ) due to emission and meteorology perturbations, and aerosol feedbacks (the two values of $\mathrm{PM}_{2.5}$ changes are for meteorology perturbations and aerosol feedbacks based on 1960 and 2010 emission levels, respectively).

\begin{tabular}{lrrrr}
\hline & $\mathrm{SO}_{4}^{2-}$ & $\mathrm{NO}_{3}^{-}$ & $\mathrm{NH}_{4}^{+}$ & $\mathrm{PM}_{2.5}$ \\
\hline Changes in $\mathrm{SO}_{2}$ emissions & $3.4(178.3 \%)$ & $-0.3(-32.3 \%)$ & $0.2(29.4 \%)$ & 3.4 \\
Changes in $\mathrm{NH}_{3}$ emissions & $0.1(5.3 \%)$ & $1.5(189.6 \%)$ & $0.6(84.0 \%)$ & 2.3 \\
Changes in $\mathrm{NO}_{x}$ emissions & $-0.7(-39.1 \%)$ & $0.6(76.0 \%)$ & $-0.04(-5.1 \%)$ & -0.2 \\
Changes in all emissions & $5.0(264.0 \%)$ & $2.6(322.5 \%)$ & $2.3(295.2 \%)$ & 9.9 \\
Changes in BC emissions & - & - & - & - \\
Changes in OC emissions & - & - & - & $-0.01 / 0.3$ \\
Temperature perturbations & - & - & - & $-0.7 /-1.1$ \\
RH perturbations & - & - & - & $-2.3 /-0.5$ \\
Wind speed perturbations & - & & & $0.1 / 0.7$ \\
Aerosol feedbacks & & & & - \\
\hline
\end{tabular}

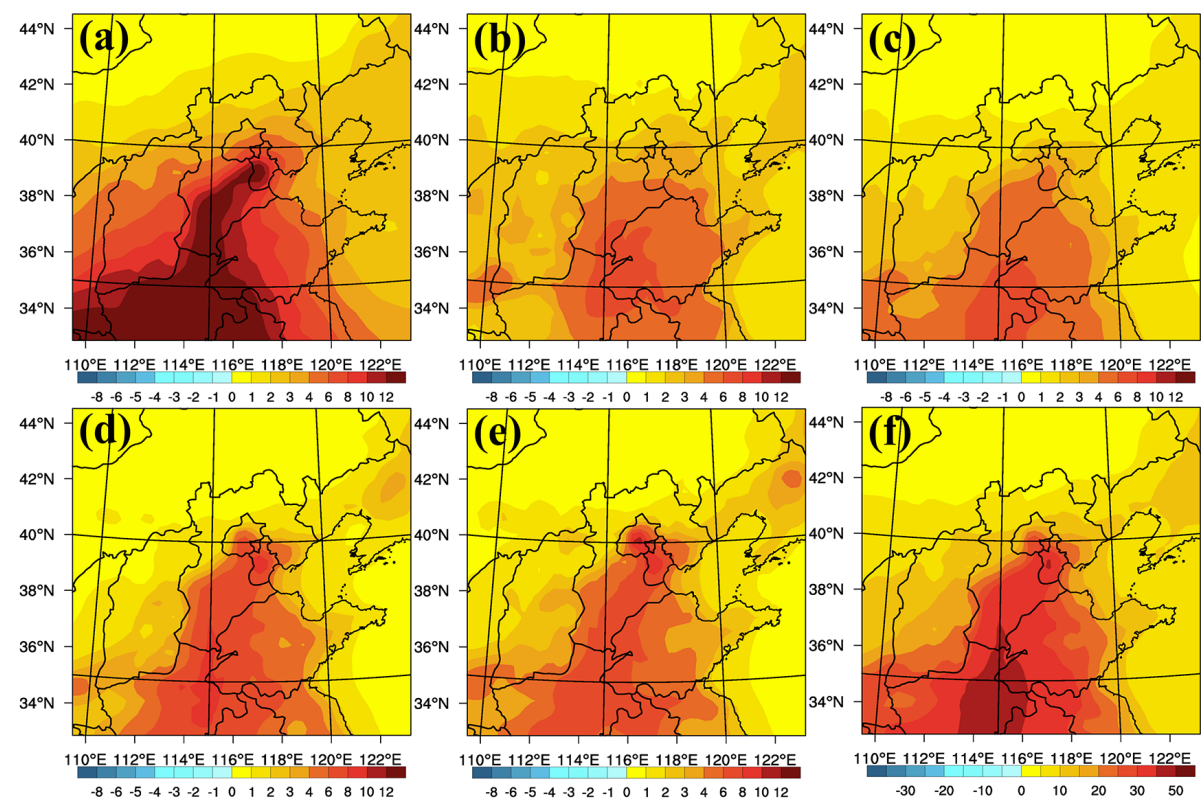

Figure 3. Predicted monthly mean changes of sulfate (a), nitrate (b), ammonium (c), BC (d), OC (e), and $\mathrm{PM}_{2.5}$ (f) due to emission changes from 1960 to 2010.

To quantify how many of the changes in Fig. 3 are from the impacts of boundary conditions, we simulated another case (BCs_1960-2010) with the innermost domain emissions fixed in 1960 and the outer domain emissions changed from 1960 to 2010. This investigation focuses on how emission changes in the outer domain affect results in the innermost domain, not accounting for the effects of global emission changes (i.e., emissions from outside the outer domain) from 1960 to 2010. The impacts of boundary conditions mostly occur around the south boundary and show nearly no impact on $\mathrm{PM}_{2.5}$ in Beijing (shown in Fig. S2), which is consistent with the continuous weak southerly winds during the study period (Gao et al., 2016). On domain average, the impacts of boundary conditions result in $5.0 \mu \mathrm{g} \mathrm{m}^{-3}$ increase in the study domain, accounting for about $33.9 \%$ of the total changes in $\mathrm{PM}_{2.5}$.

To explore how emission changes can affect haze days, we calculated the number of haze days in urban Beijing for the CTL and EMI_2010 cases, using daily mean thresholds of 35 and $75 \mu \mathrm{g} \mathrm{m}^{-3}$ (China National Ambient Air Quality Grade I and Grade II Standard; L. T. Wang et al., 2014). In urban Beijing, there are 4 days when daily mean $\mathrm{PM}_{2.5}$ concentrations are above $35 \mu \mathrm{g} \mathrm{m}^{-3}$ and 0 days with daily mean $\mathrm{PM}_{2.5}$ concentrations above $75 \mu \mathrm{g} \mathrm{m}^{-3}$ for the CTL case. For the EMI_2010 case, these two numbers increase to 15 and 8, indicating that the large increases in emissions over the past several decades have significantly affected haze occurrences in Beijing. 


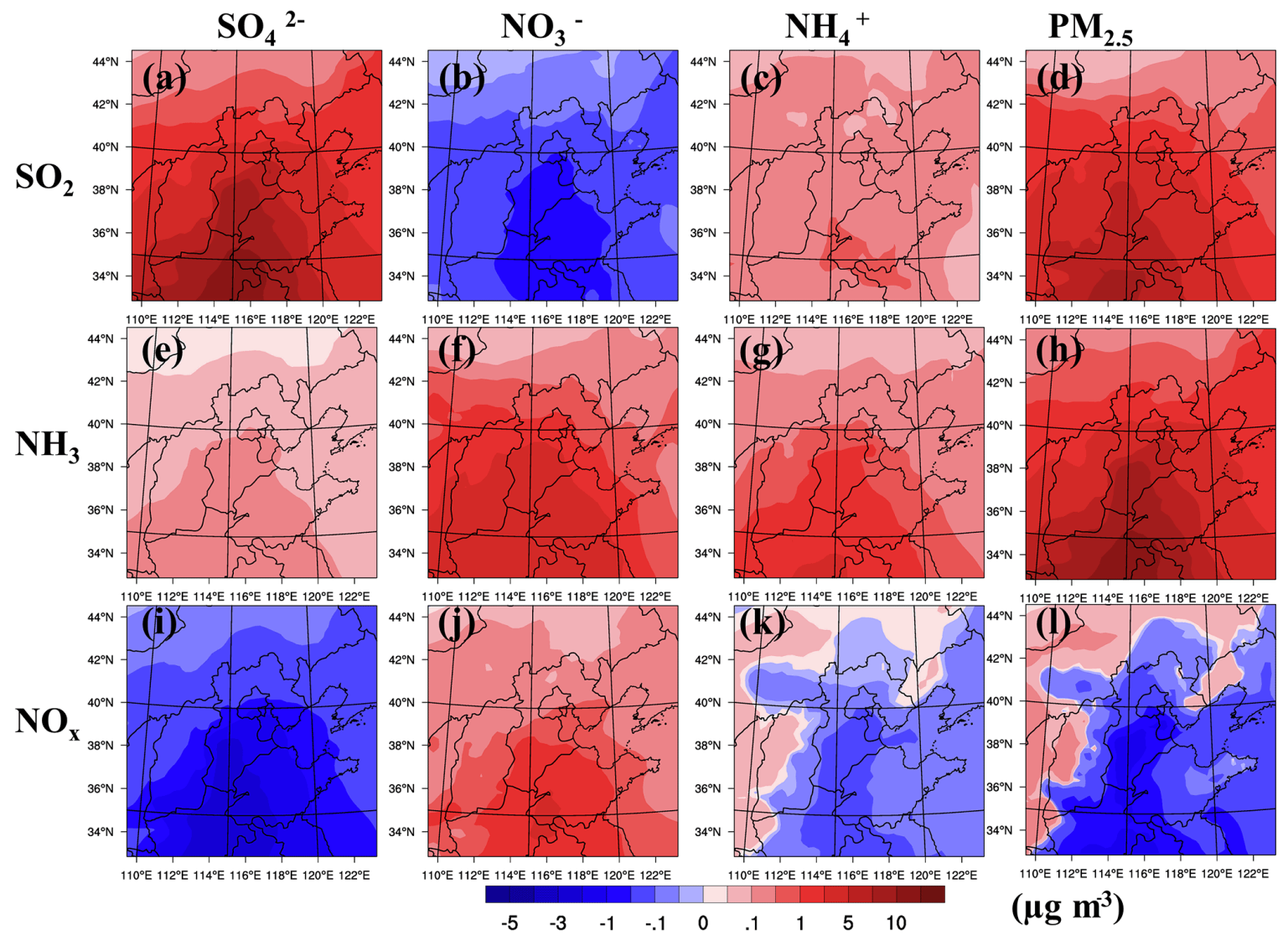

Figure 4. Responses of $\mathrm{PM}_{2.5}$ and major $\mathrm{PM}_{2.5}$ inorganic species (sulfate, nitrate, and ammonium) to individual changes in $\mathrm{SO}_{2}, \mathrm{NH}_{3}$, and $\mathrm{NO}_{x}$ emissions from 1960 to 2010 .

\subsection{Sensitivity to changes in individual emission species}

The results discussed above show that in the winter period, the concentrations of secondary inorganic aerosols (sulfate, nitrate, and ammonium) has increased dramatically. Thus it is important to explore how sensitive secondary inorganic aerosol is to perturbations in precursor emissions. Three sensitivity simulations (which change $\mathrm{SO}_{2}, \mathrm{NH}_{3}$, and $\mathrm{NH}_{3}$ emissions separately) were conducted to examine how changes in emissions of each species affect aerosol concentrations. The predicted changes of $\mathrm{PM}_{2.5}$ and major $\mathrm{PM}_{2.5}$ components at the ground level are shown in Fig. 4 and monthly domain mean aerosol changes are summarized in Table 3 .

\subsubsection{Changes in $\mathrm{SO}_{2}$ emissions}

Due to changes in $\mathrm{SO}_{2}$ emissions from 1960 to 2010, domain-averaged sulfate increase by $3.4 \mu \mathrm{g} \mathrm{m}^{-3}(178.3 \%)$, nitrate decreases by $-0.3 \mu \mathrm{g} \mathrm{m}^{-3}(-32.3 \%)$, and ammonium increases by $0.2 \mu \mathrm{g} \mathrm{m}^{-3}(29.4 \%)$. $\mathrm{NH}_{3}$ reacts preferentially with $\mathrm{SO}_{2}$ (Seinfeld and Pandis, 2012) and free $\mathrm{NH}_{3}$ reacts with enhanced $\mathrm{H}_{2} \mathrm{SO}_{4}$ due to increasing $\mathrm{SO}_{2}$. As a result, ammonium increases and less $\mathrm{HNO}_{3}$ gas is transferred to the aerosol phase, which is consistent with the responses to increasing $\mathrm{SO}_{2}$ emissions in Kharol et al. (2013).

\subsubsection{Changes in $\mathrm{NH}_{3}$ emissions}

As shown in Fig. 4 and Table 3, changes in $\mathrm{NH}_{3}$ emissions from 1960 to 2010 result in significant increases in nitrate $\left(1.5 \mu \mathrm{g} \mathrm{m}^{-3},+76.0 \%\right)$ and ammonium $\left(0.6 \mu \mathrm{g} \mathrm{m}^{-3}\right.$, $+84.0 \%)$. The domain mean changes of sulfate due to increase in $\mathrm{NH}_{3}$ are close to zero (about $0.1 \mu \mathrm{g} \mathrm{m}^{-3}$ ) because sulfate formation is only indirectly associated with $\mathrm{NH}_{3}$ availability (Tsimpidi et al., 2007). The significant changes in nitrate and ammonium occurred in south Hebei, Shandong, and Henan provinces, where anthropogenic $\mathrm{NO}_{x}$ emissions are very high (Fig. 1). Although $\mathrm{NH}_{3}$ emissions substantially increased in Inner Mongolia (Fig. 1), responses of nitrate and ammonium are not significant there due to trivial $\mathrm{NO}_{x}$ emissions. The substantial increases of nitrate after $\mathrm{NH}_{3}$ emission increase indicate that $\mathrm{NH}_{3}$ limits the $\mathrm{NH}_{4} \mathrm{NO}_{3}$ formation in North China region in this period. 

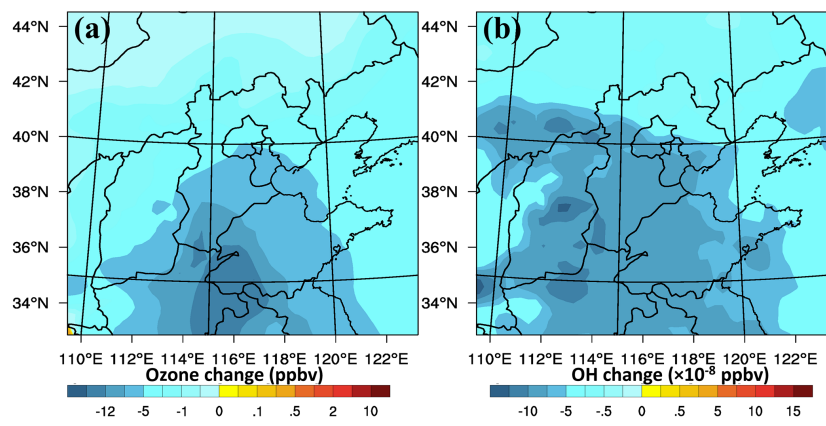

Figure 5. Daytime ozone (a) and daytime $\mathrm{OH}$ (b) changes due to $\mathrm{NO}_{x}$ emission increases.

\subsubsection{Changes in $\mathrm{NO}_{x}$ emissions}

After changing $\mathrm{NO}_{x}$ emissions from 1960 to 2010 levels, domain mean surface $\mathrm{PM}_{2.5}$ decreases by about $0.2 \mu \mathrm{g} \mathrm{m}^{-3}$, but the changes of individual $\mathrm{PM}_{2.5}$ inorganic components vary. The increase of $\mathrm{NO}_{x}$ emissions causes $0.7 \mu \mathrm{g} \mathrm{m}^{-3}(-39.1 \%)$ decrease in monthly domain mean sulfate and the domain peak sulfate reduction is about $2.9 \mathrm{\mu g} \mathrm{m}^{-3}$. The $\mathrm{OH}$ radical is critical in the sulfate formation in the regions where $\mathrm{SO}_{2}$ concentrations are high and there is a competition between $\mathrm{NO}_{x}$ and VOCs to react with $\mathrm{OH}$ (Tsimpidi et al. 2008). When the VOCs $/ \mathrm{NO}_{x}$ concentration ratio is close to $5.5: 1$, the $\mathrm{OH}$ reacts with $\mathrm{NO}_{x}$ and VOCs at an equal rate (Seinfeld and Pandis, 2012). When the concentration ratio is lower than $5.5: 1$, the $\mathrm{OH}$ primarily reacts with $\mathrm{NO}_{x}$, and a region with this concentration ratio is called a VOC-limited region. In VOClimited regions, an increase of $\mathrm{NO}_{x}$ will cause a decrease of $\mathrm{OH}$ and ozone concentration. When the VOCs $/ \mathrm{NO}_{x}$ concentration ratio is higher than $5.5: 1$, the $\mathrm{OH}$ will preferentially react with VOCs, and a region with this high ratio is called an $\mathrm{NO}_{x}$-limited region. In $\mathrm{NO}_{x}$-limited regions, an increase of $\mathrm{NO}_{x}$ will increase $\mathrm{OH}$ and ozone concentrations. In the simulated winter month, biogenic emissions are low and $\mathrm{NO}_{x}$ emissions in North China are very high, leading to lower VOCs to $\mathrm{NO}_{x}$ ratios, and thus North China can be considered a VOC-limited region. Fu et al. (2012) pointed out that northern East Asia is VOC-limited in January and urban areas of Beijing are VOC-limited in both January and July. The model averaged VOCs $/ \mathrm{NO}_{x}$ ratio changes from 4.2 to 1.2 due to emission perturbations from 1960 to 2010 (shown in Fig. S3). As a result, the large increases in $\mathrm{NO}_{x}$ emissions from 1960 to 2010 result in a $47.9 \%$ decrease in daytime surface ozone concentration and $55.6 \%$ decrease in daytime surface $\mathrm{OH}$ concentration, which are shown in Fig. 5. Over the entire domain, ozone and $\mathrm{OH}$ decrease due to $\mathrm{NO}_{x}$ emission increases (Fig. 5). Consequently, sulfate aerosol decreases over the entire domain, as shown in Fig. 4i. Decreases in sulfate might also be related to changes in thermodynamics of the ammonium-sulfate-nitrate system. Although $\mathrm{OH}$ decreases, nitrate still rises $\left(0.6 \mu \mathrm{g} \mathrm{m}^{-3},+76.0 \%\right)$ due to the
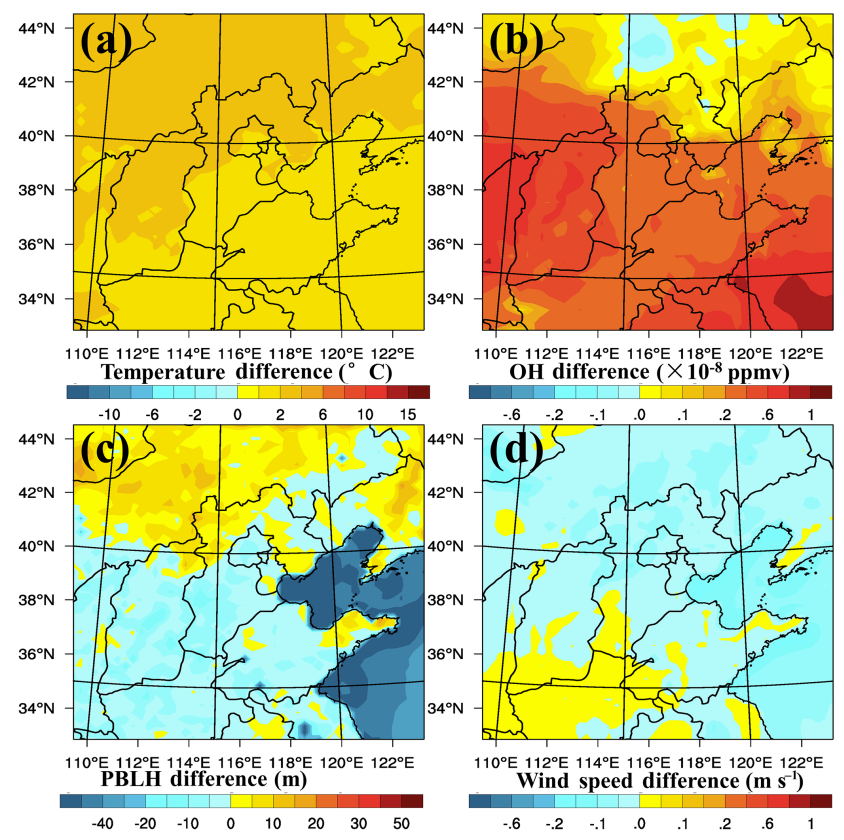

Figure 6. Monthly mean temperature difference due to perturbation in initial and boundary conditions (a), and daily mean $\mathrm{OH}(\mathbf{b})$, mean PBLH (c), and mean near-surface wind speed changes (d) due to temperature increase

increase in $\mathrm{NO}_{x}$ emissions. The domain mean ammonium decreases by about $5.1 \%\left(-0.04 \mu \mathrm{g} \mathrm{m}^{-3}\right)$. The net effects of $\mathrm{NO}_{x}$ emission increases bring about $0.2 \mu \mathrm{g} \mathrm{m}^{-3}$ decrease in monthly domain mean $\mathrm{PM}_{2.5}$ concentration and the domain peak decrease is about $1.1 \mu \mathrm{g} \mathrm{m}^{-3}$ (Table 3).

\subsubsection{Comparison of individual changes in $\mathrm{SO}_{2}, \mathrm{NH}_{3}$, and $\mathrm{NO}_{x}$ emissions to simultaneous changes in all emissions}

Here, we compare changes in major inorganic aerosols (i.e., sulfate, nitrate, and ammonium) when $\mathrm{SO}_{2}, \mathrm{NH}_{3}$, and $\mathrm{NO}_{x}$ emissions are perturbed individually to results when all emissions (including non-methane hydrocarbon) are perturbed. As shown above, increasing $\mathrm{SO}_{2}$ emissions significantly increases $\mathrm{PM}_{2.5}$ concentrations in North China region, increasing $\mathrm{NH}_{3}$ emissions also increases $\mathrm{PM}_{2.5}$ concentrations but to a lesser extent, and increasing $\mathrm{NO}_{x}$ emissions slightly decreases $\mathrm{PM}_{2.5}$ concentrations. As listed in Table 3, the monthly domain mean sulfate, nitrate, ammonium, and $\mathrm{PM}_{2.5}$ increases (resulted from changes in all emissions from 1960 to 2010) more than the effects of changing emissions separately. Domain mean sulfate increases by $5.0 \mu \mathrm{g} \mathrm{m}^{-3}$ $(+264.0 \%)$, nitrate increases by $2.6 \mu \mathrm{g} \mathrm{m}^{-3}(+322.5 \%)$, ammonium increases by $2.3 \mu \mathrm{g} \mathrm{m}^{-3}(295.2 \%)$, and $\mathrm{PM}_{2.5}$ increases by $9.9 \mu \mathrm{g} \mathrm{m}^{-3}$. The simultaneous increases in emissions promote dramatic increases of secondary inorganic aerosols in North China, which is partially due to perturbations in VOCs and other species at the same time. 


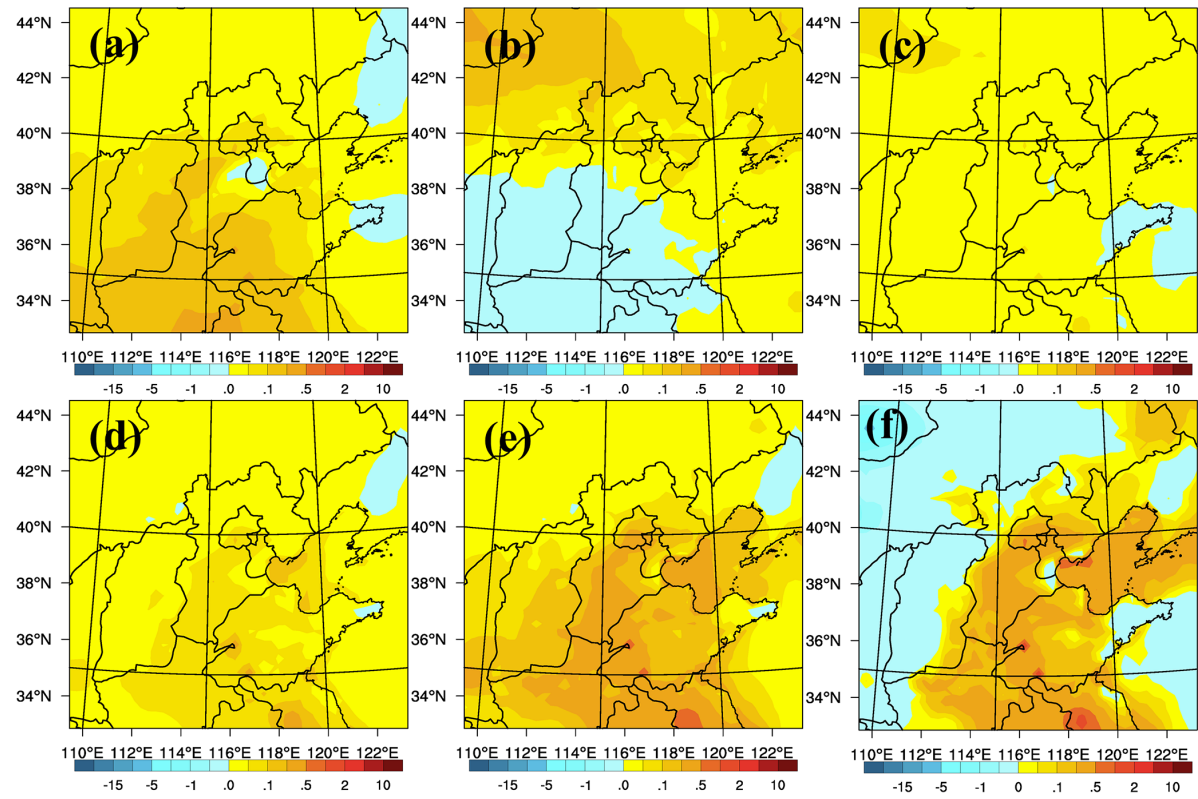

Figure 7. Monthly mean changes of sulfate (a), nitrate (b), ammonium (c), BC (d), OC (e), and $\mathrm{PM}_{2.5}$ (f) due to temperature increase.

\subsubsection{Changes in $\mathrm{BC}$ and $\mathrm{OC}$ emissions}

Since $\mathrm{BC}$ and $\mathrm{OC}$ are treated as primary aerosols in the chosen CBMZ/MOSAIC mechanism, changes in their emissions do not show any impact on other aerosol components. As listed in Table 3, monthly domain mean $\mathrm{PM}_{2.5}$ increases by 2.3 and $2.5 \mu \mathrm{g} \mathrm{m}^{-3}$ due to changes in their emissions from 1960 to 2010 , respectively.

\subsection{Effects of temperature increases}

The model used in this study is a fully online-coupled model, which simulates meteorological variables and chemical variables together. Therefore, it is not possible to increase temperature uniformly, as was done in previous studies using offline models (Dawson et al., 2007; Megartis et al., 2013, 2014). To examine the sensitivity of $\mathrm{PM}_{2.5}$ to temperature change (reflecting the winter warming trends), in the CTL_T2 simulation we decrease temperature by $2{ }^{\circ} \mathrm{C}$ in the initial and boundary conditions to reflect conditions more like those that occurred in 1960 rather than the 2010 conditions used in CTL. As a result of these changes, the monthly domain mean surface temperature increases by $2.0^{\circ} \mathrm{C}$ between CTL_T2 and CTL, but in a nonuniform manner. These responses in domain temperature are partially due to aerosol feedbacks. The spatial distributions of monthly mean surface temperature and temperature changes are shown in Fig. 6 a. The monthly mean surface temperature increases more along top left domain boundaries and less over the Bohai Sea. The influence of increasing temperature on biogenic emissions is included using temperature-sensitive biogenic emission model MEGAN (Guenther et al., 2006).
Due to the approximated change in temperature between 1960 and 2010 as mentioned above, sulfate, nitrate, ammonium, and $\mathrm{PM}_{2.5}$ are predicted to increase in most areas of the domain (Fig. 7). Predicted monthly mean sulfate increases by $0.06 \mu \mathrm{g} \mathrm{m}^{-3}(+3.1 \%)$, nitrate increases by $0.03 \mu \mathrm{g} \mathrm{m}^{-3}(+4.2 \%)$, and ammonium increases by $0.02 \mu \mathrm{g} \mathrm{m}^{-3}(+2.8 \%)$. The increases of sulfate, nitrate, and ammonium are mostly attributed to the increasing $\mathrm{OH}$ radicals, as shown in Fig. 6b. After the approximated change in temperature between 1960 and 2010, daytime $\mathrm{OH}$ increases by about $3.6 \%$ on domain average. It was found that higher temperature increased volatilization of ammonium nitrate and partitioned it to the gas phase (Megaritis et al., 2014), but it is not significant here due to the low temperature in winter. In addition, the increase of sulfate, nitrate, and ammonium could be partially due to accelerated gas-phase reaction rate at higher temperature (Dawson et al., 2007; Megaritis et al., 2014). It may be also due to enhanced photolysis caused by decreases in cloudiness after approximated change in temperature between 1960 and 2010 (as shown in Fig. S4: changes in liquid water path).

As shown in Fig. 7d-e, the concentrations of primary aerosols (BC and OC) also increase after the approximated change in temperature between 1960 and 2010. This is due to changes in other physical parameter, such as wind direction, wind speed, and planetary boundary layer heights (PBLHs), which are key factors in the diffusion of air pollutants. Figure $6 \mathrm{c}$ shows that monthly PBLHs in most North China areas decrease after the approximated change in temperature between 1960 and 2010, and PBLHs over the Bohai Sea decrease the most, with monthly mean decrease over $50 \mathrm{~m}$. The monthly domain average daytime PBLHs decrease about 

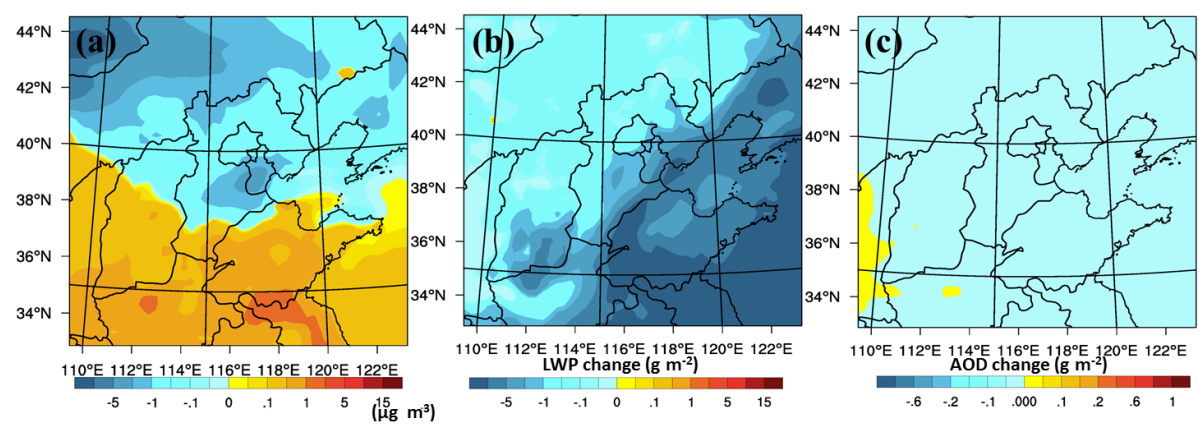

Figure 8. Monthly mean changes of $\mathrm{PM}_{2.5}$ (a), LWP (b), and AOD at $600 \mathrm{~nm}$ (c) due to RH decrease.

$2.3 \%$ due to changes in temperature vertical profiles. PBLHs highly depend on vertical profiles of temperature, and the resulting nonuniform changes in temperature modify vertical profiles of temperature, so PBLHs change. Surface horizontal winds also change (Fig. 6d), which directly affect the distributions and magnitudes of $\mathrm{PM}_{2.5}$ concentrations in North China along with PBLH changes.

The responses of $\mathrm{PM}_{2.5}$ concentrations to approximated change in temperature between 1960 and 2010 are different from the responses of sulfate, nitrate, ammonium, BC, and OC (Fig. 7), with decreases in northwestern regions and increases in most areas of the North China Plain. This is because natural dust is dominant in northwestern regions (as shown in Fig. 2f), and the concentrations of natural dust decrease under lower horizontal wind speeds (Fig. 6d). The monthly $\mathrm{PM}_{2.5}$ concentration decreases by $0.01 \mu \mathrm{g} \mathrm{m}^{-3}$ on domain average due to the approximated change in temperature between 1960 and 2010. Because of temperature increase, the numbers of haze days (defined using the daily mean threshold 35 and $75 \mu \mathrm{g} \mathrm{m}^{-3}$ ) in urban Beijing do not change.

The discussions shown above are based on emission levels in 1960. The responses to the approximated change in temperature between 1960 and 2010 were also investigated based on emission levels in 2010, and the results are shown in Figs. S5, S6, and Table 3. The spatial distributions of the changes are similar to the results shown above but with larger magnitudes. The domain mean PBLHs decrease slightly more $(-8.6$ compared to $-8.3 \mathrm{~m})$. The domain mean $\mathrm{PM}_{2.5}$ concentrations and $\mathrm{PM}_{2.5}$ components exhibit larger increases in North China, although daytime OH concentrations increases less $\left(2.6 \times 10^{-9}\right.$ compared to $3.3 \times 10^{-9} \mathrm{ppmv}$ ), suggesting that the responses of $\mathrm{PM}_{2.5}$ concentrations are mostly due to changes in PBLHs and wind fields.

\subsection{Effects of RH decreases}

The RH was enhanced by $10 \%$ in model initial and boundary conditions in CTL_RH10 to represent RH for the previous decades. As a result, the simulated monthly mean $\mathrm{RH}$ decreases by $9.3 \%$ on domain average between CTL_RH10 and CTL. Due to the approximated change in RH between 1960 and 2010, domain mean $\mathrm{PM}_{2.5}$ concentration decreases by $0.7 \mu \mathrm{g} \mathrm{m}^{-3}$. As shown Fig. $8 \mathrm{a}, \mathrm{PM}_{2.5}$ concentrations decrease in the Jing-Jin-Ji region but increase in southern areas of the domain. The ammonium nitrate formation equilibrium depends on RH (Tai et al., 2010), so $\mathrm{HNO}_{3}$ may be shifted to the gas phase under lower RH. In addition, the changes in $\mathrm{RH}$ can also affect the wet deposition rate. The increases in southern areas of the domain are mainly due to suppressed in-cloud scavenging, as the decreases in RH inhibit the formation of clouds. As shown in Fig. 8b, liquid water path decreases by $75.0 \%$. As a result, the in-cloud scavenging loss rate decreases. The changes of predicted aerosol optical depth at $600 \mathrm{~nm}$ are shown in Fig. 8c. In most regions, visibility decreases due to lower RH. Because RH decreases, the numbers of haze days (defined using the daily mean threshold 35 and $75 \mu \mathrm{g} \mathrm{m}^{-3}$ ) in urban Beijing do not change. The responses to the approximated change in RH between 1960 and 2010 were also investigated based on emission levels in 2010, and the results are shown in Fig. S7 and Table 3. The responses are also similar to changes based on emission levels in 1960, but with larger magnitudes.

\subsection{Effects of wind speed decreases}

Simulations were also carried out when wind speeds in initial and boundary conditions were increased in CTL_WS20 to estimate the wind speeds for the previous decades. The predicted domain-averaged monthly mean wind speed decreases by about $0.7 \mathrm{~m} \mathrm{~s}^{-1}$ between CTL_WS20 and CTL. As shown in Fig. 9a, the monthly mean near-surface horizontal winds are pronounced in mountainous areas (northwest areas of the domain) and relatively smaller in other areas. Figure $9 \mathrm{~b}$ shows the changes of wind speeds (CTLWS20) due to model perturbations. The predicted monthly mean $\mathrm{PM}_{2.5}$ concentrations decrease by $2.3 \mu \mathrm{g} \mathrm{m}^{-3}$ on domain average, but the responses of $\mathrm{PM}_{2.5}$ vary within the domain. As shown in Fig. 9c, $\mathrm{PM}_{2.5}$ concentrations decrease in the northwestern areas because of lower production of natural dust under lower horizontal wind speeds. However, in 

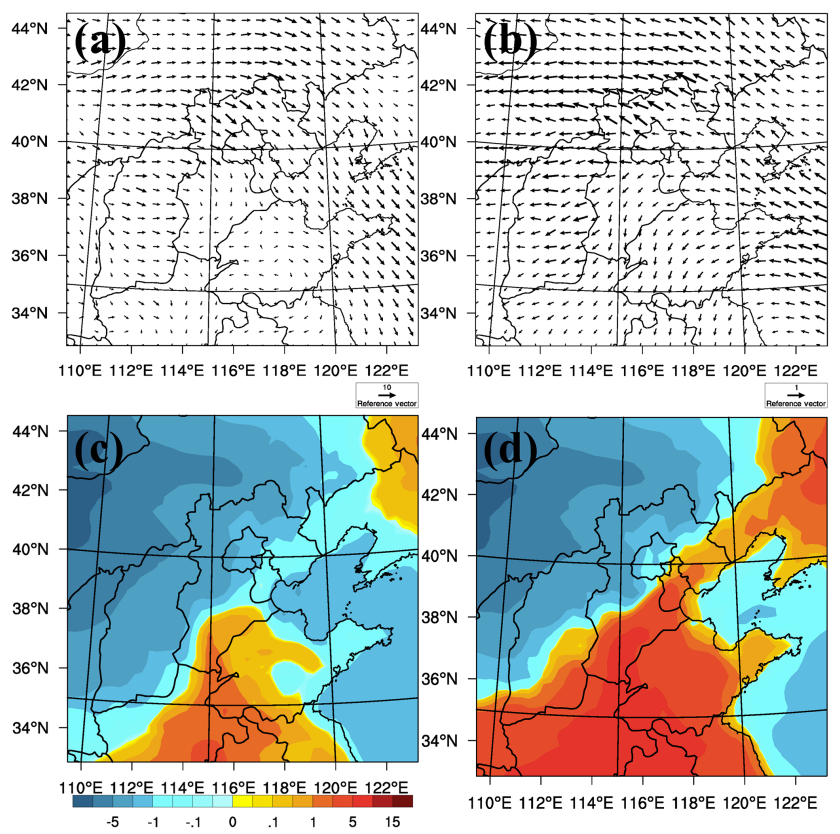

Figure 9. Monthly mean wind fields for WS20 case (a) and changes of wind speeds (CTL-CTL_WS20) (b), and mean changes of $\mathrm{PM}_{2.5}$ concentrations based on 1960 emission levels (c) and 2010 emission levels (d).

most areas of the North China Plain, $\mathrm{PM}_{2.5}$ concentrations increase under lower wind speeds (Fig. 9c). The domain peak increase is about $2.4 \mu \mathrm{g} \mathrm{m}^{-3}$, which is based on low predicted $\mathrm{PM}_{2.5}$ concentrations using emissions for year 1960. If the concentration in base case is higher, the responses will be enhanced. As shown in Fig. 9d, the domain maximum increases in $\mathrm{PM}_{2.5}$ increases from 2.4 to $9.4 \mu \mathrm{g} \mathrm{m}^{-3}$. Because of wind speed decreases, the number of haze days that daily mean $\mathrm{PM}_{2.5}$ concentrations are above $35 \mu \mathrm{g} \mathrm{m}^{-3}$ increases by 1 .

\subsection{Effects of changes in aerosol feedbacks}

As mentioned in Gao et al. (2016), high concentrations of aerosol enhance stability of boundary layer and increase $\mathrm{PM}_{2.5}$ concentrations. Due to dramatic changes in emissions from 1960 to 2010, the strength of aerosol feedbacks may also have changed. To quantify these changes, we simulated four cases (i.e., CTL, CTL_NF, EMI2010, and EMI2010_NF).CTL-CLT_NF and EMI2010-EMI2010_NF are used to represent the contributions of aerosol radiative effects in 1960 and 2010. The changes in monthly mean daytime PBLHs and $\mathrm{PM}_{2.5}$ concentrations are shown in Fig. 10. In 1960, the domain-averaged PBLH decreases by $6.7 \mathrm{~m}$ due to aerosol radiative effects, and the domain maximum decrease is $25.4 \mathrm{~m}$. Correspondingly, the domain-averaged $\mathrm{PM}_{2.5}$ increases by $0.1 \mu \mathrm{g} \mathrm{m}^{-3}$ and the domain maximum increase is $0.9 \mu \mathrm{g} \mathrm{m}^{-3}$. In 2010, the domain-averaged PBLH decreases by $13.8 \mathrm{~m}$ and the domain maximum decrease is $55.2 \mathrm{~m}$ (more than 2 times that of 1960). Correspondingly,
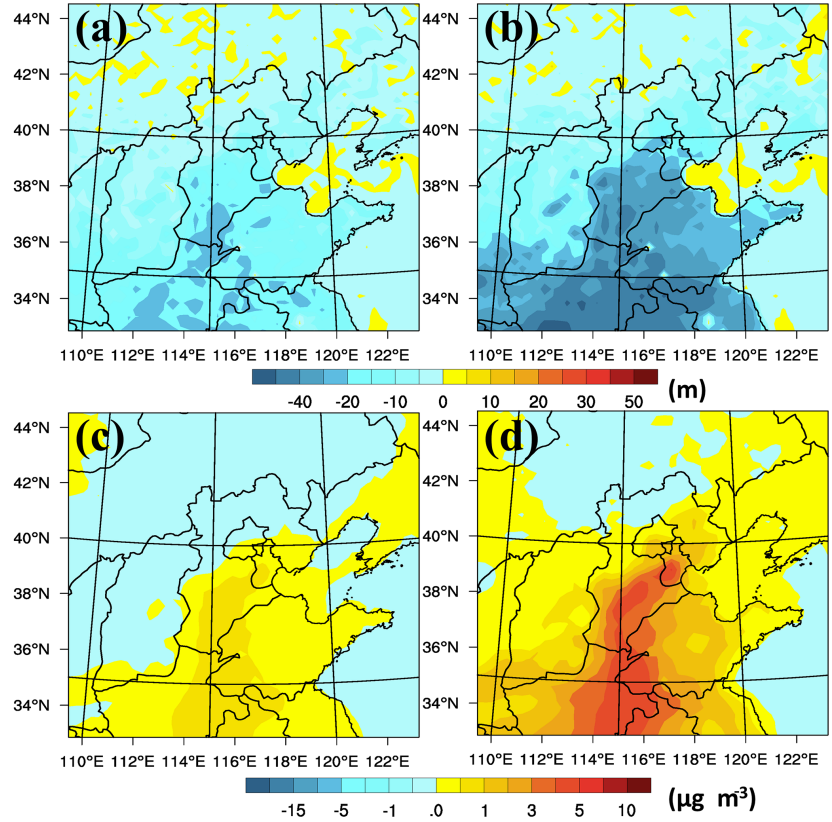

Figure 10. Monthly mean changes of daytime PBLHs for year 1960 (a) and 2010 (b) and of daytime $\mathrm{PM}_{2.5}$ concentrations for year 1960 (c) and 2010 (d) due to aerosol-radiation interactions.

the domain-averaged $\mathrm{PM}_{2.5}$ increases by $0.7 \mu \mathrm{g} \mathrm{m}^{-3}$ and the domain maximum increase is $5.1 \mu \mathrm{g} \mathrm{m}^{-3}$. The enhanced strength of aerosol feedbacks is another important cause of degraded aerosol pollution. Thus, controlling emissions will have a co-benefit of reducing strength of aerosol feedbacks.

\subsection{Implications for the effects of emission and meteorology changes on $\mathbf{P M}_{2.5}$ concentrations}

The simulated responses of $\mathrm{PM}_{2.5}$ concentrations to emission changes and meteorology changes presented here, along with the previous presented effects of aerosol feedbacks (Gao et al., 2016), provide important implications for the causes of the dramatic increases in winter $\mathrm{PM}_{2.5}$ concentrations.

We calculated domain maximum changes in $\mathrm{PM}_{2.5}$ concentration averaged over 4 stagnant days (16-19 January) owing to emission changes from 1960 to 2010 (EMI2010-CTL), temperature increases (CTL-CTL_T2), RH decreases (CTL-CTL_RH10), wind speed decreases (CTL-CTL_RH20), and aerosol feedbacks (CTL-CTL_NF). The values are 137.7, 2.0, 2.6, 7.5, and $4.0 \mu \mathrm{g} \mathrm{m}^{-3}$, respectively. When the perturbations are based on emission levels in 2010, domain maximum changes in $\mathrm{PM}_{2.5}$ concentration due to temperature increases (EMI2010-EMI2010_T2), RH decreases (EMI2010-EMI2010_RH10), wind speed decreases (EMI2010-EMI2010_WS20), and aerosol feedbacks (EMI2010-EMI2010_NF) are 4.8, 4.7, 26.4, and $25.5 \mu \mathrm{g} \mathrm{m}^{-3}$. The effects of emission changes on haze formation are dominant and the effects of aerosol feedbacks are comparable to the effects of wind speed decreases. 
The comprehensive comparisons of these factors are also summarized in Table 3. Based on the monthly domain mean responses of $\mathrm{PM}_{2.5}$ concentrations to these factors, dramatic emission changes due to urbanization and industrialization are the main causes of degraded air quality and frequent haze occurrences in North China. $\mathrm{PM}_{2.5}$ shows significant responses to changes in $\mathrm{SO}_{2}, \mathrm{NH}_{3}$, and $\mathrm{NO}_{x}$ emissions than $\mathrm{BC}$ and $\mathrm{OC}$ (about $106.3 \%$ higher). In addition, $\mathrm{PM}_{2.5}$ shows significant increases in response to changes in $\mathrm{SO}_{2}$ and $\mathrm{NH}_{3}$ emissions, as compared to increases in response to changes in $\mathrm{NO}_{x}$ emissions. This region is relatively ammonia-poor in winter, so reducing $\mathrm{NH}_{3}$ emissions might be effective, which is consistent with previous findings in Europe (Megaritis et al., 2013). $\mathrm{SO}_{2}$ is the precursor of sulfate, which accounts for a large fraction of PM in this region. Thus, they should be preferentially controlled in order to reduce $\mathrm{PM}_{2.5}$ levels. To control $\mathrm{SO}_{2}$ emissions, the usage of natural gas or other clean energy should be promoted to reduce the usage of coal. $\mathrm{NH}_{3}$ emissions in China are mainly from agriculture sources (about $90 \%$ ), including livestock, fertilizer, and agricultural soil (Huang et al., 2012). Lelieveld et al. (2015) found that agricultural emissions make the largest relative role in $\mathrm{PM}_{2.5}$ concentration in eastern USA, Europe, Russia, and East Asia. To control $\mathrm{NH}_{3}$ emissions from agriculture sources, some animal feeding and animal housing strategies should be taken. In addition, controlling emissions will also have a co-benefit of reducing strength of aerosol feedbacks.

According to the ECLIPSE_GAINS_4a emission dataset, $\mathrm{SO}_{2}$ emissions in China will decrease by $-26 \%, \mathrm{NO}_{x}$ emissions in China will increase by $19 \%$, and $\mathrm{NH}_{3}$ emissions in China will increase by $14 \%$ from 2010 to 2030 . We predicted (EMI_2030: by perturbing $\mathrm{SO}_{2}, \mathrm{NO}_{x}$, and $\mathrm{NH}_{3}$ emissions by $-26,19$, and $14 \%$ ) that these changes will lead to large decreases in winter sulfate $\left(-2.3 \mu \mathrm{g} \mathrm{m}^{-3}\right.$ on domain average). Nitrate will increase by $1.5 \mu \mathrm{g} \mathrm{m}^{-3}$ and ammonium will slightly decrease $\left(-0.05 \mu \mathrm{g} \mathrm{m}^{-3}\right)$ on domain average. The net change of domain-averaged $\mathrm{PM}_{2.5}$ concentration is not significant $\left(-0.8 \mu \mathrm{g} \mathrm{m}^{-3}\right)$, so more efforts are needed to control these important gaseous precursors.

From the information listed in Table 3, the responses of $\mathrm{PM}_{2.5}$ concentrations to approximated changes in temperature and RH between 1960 and 2010 are not as significant as to approximated change in wind speed between 1960 and 2010. From Sect. 3.3, we also found that the effects of approximated changes in temperature between 1960 and 2010 on $\mathrm{PM}_{2.5}$ concentration are dominant by changes in PBLH and wind fields. Previous studies have pointed out the occurrences of haze events are highly associated with atmospheric circulation anomalies (Chen and Wang, 2015; Zhang et al., 2016). Thus, changes in atmospheric circulations may be another important cause of growing haze pollution in addition to emission changes. Furthermore, aerosol can also change atmospheric circulation, especially in severely polluted East Asia. Thus, controlling emission may have co-benefits of mitigate aerosol effects on atmospheric circulation.
The effects of changing atmospheric circulations on winter haze pollution in China is beyond the scope of this paper but should be investigated in future studies.

\section{Summary}

A fully online-coupled meteorological and chemical transport model, WRF-Chem was used to study responses of winter $\mathrm{PM}_{2.5}$ concentrations to changes in emissions of $\mathrm{SO}_{2}, \mathrm{BC}$, $\mathrm{OC}, \mathrm{NH}_{3}$, and $\mathrm{NO}_{x}$ and to meteorology (temperature, $\mathrm{RH}$, and wind speeds) changes in North China region, where people suffer due to severe winter haze pollution.

The detailed historical emissions dataset MACCity for year 1960 and 2010 were used to evaluate the impacts of changes in emissions of $\mathrm{SO}_{2}, \mathrm{BC}$, and OC. From 1960 to 2010, the dramatic changes in emissions lead to $+264.0 \%$ increases in sulfate, $+322.5 \%$ increases in nitrate, $+295.2 \%$ increases in ammonium, $+157.0 \%$ increases in BC, and $54 \%$ increases in OC. The domain mean $\mathrm{PM}_{2.5}$ concentrations increase by $14.7 \mu \mathrm{g} \mathrm{m}^{-3}$ and the domain maximum increase is about $45 \mu \mathrm{g} \mathrm{m}^{-3}$. The responses of $\mathrm{PM}_{2.5}$ to individual emission species indicate that the simultaneous increases in $\mathrm{SO}_{2}, \mathrm{NH}_{3}$, and $\mathrm{NO}_{x}$ emissions dominated the increases in $\mathrm{PM}_{2.5}$ concentrations. $\mathrm{PM}_{2.5}$ shows significant increases in response to $\mathrm{SO}_{2}$ and $\mathrm{NH}_{3}$ emission changes. The increases in $\mathrm{NO}_{x}$ emissions may decrease surface ozone concentration and surface $\mathrm{OH}$ radical concentrations, because North China region is VOC-limited in the winter. In addition, OC accounts for a large fraction in $\mathrm{PM}_{2.5}$ changes.

The sensitivities of $\mathrm{PM}_{2.5}$ to emission changes of its precursors provide some implications for haze pollution control. $\mathrm{SO}_{2}, \mathrm{NH}_{3}$, and $\mathrm{OC}$ should be preferentially controlled. In China, the residential sector, particularly biofuel usage is the primary sources of OC ( $\mathrm{Lu}$ et al., 2011). The usage of natural gas or other clean energy should be promoted to reduce the usage of coal and biofuel to reduce $\mathrm{SO}_{2}$ and OC. To control $\mathrm{NH}_{3}$ emissions from agriculture sources, some animal feeding and animal housing strategies should be taken.

The effects of changes in winter time meteorology conditions were also studied. Emission changes from 1960 to 2010 substantially increase numbers of haze days, but meteorology perturbations do not show any significant impacts. The approximated changes in temperature and RH between 1960 and 2010 do change $\mathrm{PM}_{2.5}$ concentrations, but the strength is not as significant as the effects of wind speed and emission changes. The effects of the approximated changes in temperature between 1960 and 2010 are dominated by the changes in surface wind fields and PBLHs. The effect of aerosol feedbacks is comparable to the effect of decreasing wind speeds and the strength of aerosol feedbacks significantly increased from 1960 to 2010.

The above discussions indicate that aerosol concentrations are mainly controlled by atmospheric circulations, except emission changes. Thus, long-term trends in atmospheric cir- 
culations may be another important cause of winter haze events in North China. More studies are necessary to get a better understanding of the aerosol-circulation interactions.

In our previous modeling study of the same period (January 2010), we found that SOA contribution was small, so we did not include SOA in this study. However, this indication might be problematic due to current poorly parameterized SOA scheme. In the future, how changes in emissions and meteorology variables affect productions of SOA during winter should be further studied using more advanced SOA schemes. In addition, we did not consider primary PM except $\mathrm{BC}$ and $\mathrm{OC}$ in the model because there is no information in the MACCity emission inventory, which is another direction for improvements in future studies.

\section{Data availability}

Contact Meng Gao (meng-gao@uiowa.edu) or Gregory R. Carmichael (gcarmich@engineering.uiowa.edu) for data requests.

\section{The Supplement related to this article is available online at doi:10.5194/acp-16-11837-2016-supplement.}

Acknowledgements. This work was supported in part by grants from NASA Applied Science (NNX11AI52G) and EPA STAR (RD-83503701) programs. We thank the ECCAD website for providing the MACCity emission inventory. We also would like to thank Yafang Cheng for her contributions to the development of emission processing model.

Edited by: C. Hogrefe

Reviewed by: two anonymous referees

\section{References}

Aksoyoglu, S., Keller, J., Barmpadimos, I., Oderbolz, D., Lanz, V. A., Prévôt, A. S. H., and Baltensperger, U.: Aerosol modelling in Europe with a focus on Switzerland during summer and winter episodes, Atmos. Chem. Phys., 11, 7355-7373, doi:10.5194/acp11-7355-2011, 2011.

Andreani-Aksoyoglu, S., Keller, J., Prévôt, A. S. H., Baltensperger, U., and Flemming, J.: Secondary aerosols in Switzerland and northern Italy: Modeling and sensitivity studies for summer 2003, J. Geophys. Res.-Atmos., 113, 1-12, doi:10.1029/2007JD009053, 2008.

Aw, J. and Kleeman, M. J.: Evaluating the first-order effect of intraannual temperature variability on urban air pollution, J. Geophys. Res., 108, 4365, doi:10.1029/2002JD002688, 2003.

Chen, H. P. and Wang, H. J.: Haze days in North China and the associated atmospheric circulations based on daily visibility data from 1960 to 2012, J. Geophys. Res.-Atmos., 120, 5895-5909, doi:10.1002/2015JD023225, 2015.
Cheung, H. C., Wang, T., Baumann, K., and Guo, H.: Influence of regional pollution outflow on the concentrations of fine particulate matter and visibility in the coastal area of southern China, Atmos. Environ., 39, 6463-6474, doi:10.1016/j.atmosenv.2005.07.033, 2005.

Dawson, J. P., Adams, P. J., and Pandis, S. N.: Sensitivity of $\mathrm{PM}_{2.5}$ to climate in the Eastern US: a modeling case study, Atmos. Chem. Phys., 7, 4295-4309, doi:10.5194/acp-7-4295-2007, 2007.

Dawson, J. P., Bloomer, B. J., Winner, D. A., and Weaver, C. P.: Understanding the meteorological drivers of U.S. particulate matter concentrations in a changing climate, B. Am. Meteorol. Soc., 95, 521-532, doi:10.1175/BAMS-D-12-00181.1, 2014.

Emery, C., Tai, E., and Yarwood, G.: Enhanced Meteorological Modeling and Performance Evaluation for Two Texas Ozone Episodes, in Prepared for the Texas Natural Resource Conservation Commission, ENVIRON International Corporation, Novato, CA, 2001.

Emmons, L. K., Walters, S., Hess, P. G., Lamarque, J.-F., Pfister, G. G., Fillmore, D., Granier, C., Guenther, A., Kinnison, D., Laepple, T., Orlando, J., Tie, X., Tyndall, G., Wiedinmyer, C., Baughcum, S. L., and Kloster, S.: Description and evaluation of the Model for Ozone and Related chemical Tracers, version 4 (MOZART-4), Geosci. Model Dev., 3, 43-67, doi:10.5194/gmd3-43-2010, 2010.

Fu, G. Q., Xu, W. Y., Yang, R. F., Li, J. B., and Zhao, C. S.: The distribution and trends of fog and haze in the North China Plain over the past 30 years, Atmos. Chem. Phys., 14, 11949-11958, doi:10.5194/acp-14-11949-2014, 2014.

Fu, J. S., Dong, X., Gao, Y., Wong, D. C., and Lam, Y. F.: Sensitivity and linearity analysis of ozone in East Asia: The effects of domestic emission and intercontinental transport, J. Air Waste Manage. As., 62, 1102-1114, doi:10.1080/10962247.2012.699014, 2012.

Gao, M., Guttikunda, S. K., Carmichael, G. R., Wang, Y., Liu, Z., Stanier, C. O., Saide, P. E., and Yu, M.: Health impacts and economic losses assessment of the 2013 severe haze event in Beijing area, Sci. Total Environ., 511, 553-561, doi:10.1016/j.scitotenv.2015.01.005, 2015.

Gao, M., Carmichael, G. R., Wang, Y., Saide, P. E., Yu, M., Xin, J., Liu, Z., and Wang, Z.: Modeling study of the 2010 regional haze event in the North China Plain, Atmos. Chem. Phys., 16, 1673-1691, doi:10.5194/acp-16-1673-2016, 2016.

Granier, C., Bessagnet, B., Bond, T., D’Angiola, A., Denier van der Gon, H., Frost, G. J., Heil, A., Kaiser, J. W., Kinne, S., Klimont, Z., Kloster, S., Lamarque, J.-F., Liousse, C., Masui, T., Meleux, F., Mieville, A., Ohara, T., Raut, J.-C., Riahi, K., Schultz, M. G., Smith, S. J., Thompson, A., van Aardenne, J., van der Werf, G. R., and van Vuuren, D. P.: Evolution of anthropogenic and biomass burning emissions of air pollutants at global and regional scales during the 1980-2010 period, Climatic Change, 109, 163-190, doi:10.1007/s10584-011-0154-1, 2011.

Guenther, A., Karl, T., Harley, P., Wiedinmyer, C., Palmer, P. I., and Geron, C.: Estimates of global terrestrial isoprene emissions using MEGAN (Model of Emissions of Gases and Aerosols from Nature), Atmos. Chem. Phys., 6, 3181-3210, doi:10.5194/acp-63181-2006, 2006

Guo, W.-L., Hong-Bo, S., Jing-Jin, M., Ying-Juan, Z., Ji, W., WenJun, S., and Zi-Yin, Z.: Basic Features of Climate Change in 
North China during 1961-2010, Adv. Clim. Chang. Res., 4, 7383, doi:10.3724/SP.J.1248.2013.073, 2013.

Heald, C. L., Henze, D. K., Horowitz, L. W., Feddema, J., Lamarque, J. F., Guenther, A., Hess, P. G., Vitt, F., Seinfeld, J. H., Godstein, A. H., and Fung, I.: Predicted change in global secondary organic aerosol concentrations in response to future climate, emissions, and land use change, J. Geophys. Res.-Atmos., 113, 1-16, doi:10.1029/2007JD009092, 2008.

$\mathrm{Hu}$, Z.-Z.: Long-term climate variations in China and global warming signals, J. Geophys. Res., 108, 1-13, doi:10.1029/2003JD003651, 2003.

Huang, X., Song, Y., Li, M., Li, J., Huo, Q., Cai, X., Zhu, T., Hu, M., and Zhang, H.: A high-resolution ammonia emission inventory in China, Global Biogeochem. Cy., 26, GB1030, doi:10.1029/2011GB004161, 2012.

Jacob, D. J. and Winner, D. A.: Effect of climate change on air quality, Atmos. Environ., 43, 51-63, doi:10.1016/j.atmosenv.2008.09.051, 2009.

Jia, B., Wang, Y., Yao, Y., and Xie, Y.: A new indicator on the impact of large-scale circulation on wintertime particulate matter pollution over China, Atmos. Chem. Phys., 15, 11919-11929, doi:10.5194/acp-15-11919-2015, 2015.

Jiménez-Guerrero, P., Montávez, J. P., Gómez-Navarro, J. J., Jerez, S., and Lorente-Plazas, R.: Impacts of climate change on ground level gas-phase pollutants and aerosols in the Iberian Peninsula for the late XXI century, Atmos. Environ., 55, 483-495, doi:10.1016/j.atmosenv.2012.02.048, 2012.

Kharol, S. K., Martin, R. V., Philip, S., Vogel, S., Henze, D. K., Chen, D., Wang, Y., Zhang, Q., and Heald, C. L.: Persistent sensitivity of Asian aerosol to emissions of nitrogen oxides, Geophys. Res. Lett., 40, 1021-1026, doi:10.1002/grl.50234, 2013.

Lelieveld, J., Evans, J. S., Fnais, M., Giannadaki, D., and Pozzer, A.: The contribution of outdoor air pollution sources to premature mortality on a global scale, Nature, 525, 367-371, doi:10.1038/nature15371, 2015.

Leng, C., Duan, J., Xu, C., Zhang, H., Wang, Y., Wang, Y., Li, X., Kong, L., Tao, J., Zhang, R., Cheng, T., Zha, S., and Yu, X.: Insights into a historic severe haze event in Shanghai: synoptic situation, boundary layer and pollutants, Atmos. Chem. Phys., 16, 9221-9234, doi:10.5194/acp-16-9221-2016, 2016.

Li, C., Martin, R. V., Boys, B. L., van Donkelaar, A., and Ruzzante, S.: Evaluation and application of multi-decadal visibility data for trend analysis of atmospheric haze, Atmos. Chem. Phys., 16, 2435-2457, doi:10.5194/acp-16-2435-2016, 2016.

Li, M., Zhang, Q., Kurokawa, J., Woo, J.-H., He, K. B., Lu, Z., Ohara, T., Song, Y., Streets, D. G., Carmichael, G. R., Cheng, Y. F., Hong, C. P., Huo, H., Jiang, X. J., Kang, S. C., Liu, F., Su, H., and Zheng, B.: MIX: a mosaic Asian anthropogenic emission inventory for the MICS-Asia and the HTAP projects, Atmos. Chem. Phys. Discuss., 15, 34813-34869, doi:10.5194/acpd-1534813-2015, 2015.

Li, K., Liao, H., Mao, Y., and Ridley, D. A.: Source sector and region contributions to concentration and direct radiative forcing of black carbon in China, Atmos. Environ., 124, 351-366, doi:10.1016/j.atmosenv.2015.06.014, 2016.

Lu, Z., Zhang, Q., and Streets, D. G.: Sulfur dioxide and primary carbonaceous aerosol emissions in China and India, 1996-2010, Atmos. Chem. Phys., 11, 9839-9864, doi:10.5194/acp-11-98392011, 2011.
Megaritis, A. G., Fountoukis, C., Charalampidis, P. E., Pilinis, C., and Pandis, S. N.: Response of fine particulate matter concentrations to changes of emissions and temperature in Europe, Atmos. Chem. Phys., 13, 3423-3443, doi:10.5194/acp-13-34232013, 2013.

Megaritis, A. G., Fountoukis, C., Charalampidis, P. E., Denier van der Gon, H. A. C., Pilinis, C., and Pandis, S. N.: Linking climate and air quality over Europe: effects of meteorology on $\mathrm{PM}_{2.5}$ concentrations, Atmos. Chem. Phys., 14, 10283-10298, doi:10.5194/acp-14-10283-2014, 2014.

$\mathrm{Mu}, \mathrm{Q}$. and Liao, H.: Simulation of the interannual variations of aerosols in China: role of variations in meteorological parameters, Atmos. Chem. Phys., 14, 9597-9612, doi:10.5194/acp-149597-2014, 2014.

Pay, M. T., Jiménez-Guerrero, P., and Baldasano, J. M.: Assessing sensitivity regimes of secondary inorganic aerosol formation in Europe with the CALIOPE-EU modeling system, Atmos. Environ., 51, 146-164, doi:10.1016/j.atmosenv.2012.01.027, 2012.

Petäjä, T., Järvi, L., Kerminen, V., Ding, A. J., Sun, J. N., Nie, W., and Kujansuu, J.: Enhanced air pollution via aerosolboundary layer feedback in China, Sci. Rep., 6, 18998, doi:10.1038/srep18998, 2016.

Pope, C. A., Ezzati, M., and Dockery, D. W.: Fine-Particulate Air Pollution and Life Expectancy in the United States, N. Engl. J. Med., 340, 376-386, doi:10.1056/NEJMsa0805646, 2009.

Ren, G., Ding, Y., Zhao, Z., Zheng, J., and Wu, T.: Recent progress in studies of climate change in China, Adv. Atmos., 29, 958-977, doi:10.1007/s00376-012-1200-2, 2012.

Seinfeld, J. H. and Pandis, S. N.: Atmospheric chemistry and physics: from air pollution to climate change, John Wiley \& Sons, Inc., Hoboken, New Jersey, 2012.

Sheehan, P. E. and Bowman, F. M.: Estimated effects of temperature on secondary organic aerosol concentrations, Environ. Sci. Technol., 35, 2129-2135, 2001.

Shi, P.-J., Zhang, G.-F., Kong, F., and Ye, Q.: Wind speed change regionalization in China (1961-2012), Adv. Clim. Chang. Res., 6, 151-158, doi:10.1016/j.accre.2015.09.006, 2015.

Song, Y., Liu, Y., and Ding, Y.: A Study of Surface Humidity Changes in China During the Recent 50 Years, Acta Meteorol. Sin., 26, 541-553, doi:10.1007/s13351-012-0501-9, 2012.

Steiner, A. L., Tonse, S., Cohen, R. C., Goldstein, A. H., and Harley, R. A.: Influence of future climate and emissions on regional air quality in California, J. Geophys. Res.-Atmos., 111, 1-22, doi:10.1029/2005JD006935, 2006.

Tagaris, E., Manomaiphiboon, K., Liao, K. J., Leung, L. R., Woo, J. H., He, S., Amar, P., and Russell, A. G.: Impacts of global climate change and emissions on regional ozone and fine particulate matter concentrations over the United States, J. Geophys. Res.-Atmos., 112, D14312, doi:10.1029/2006JD008262, 2007.

Tai, A. P. K., Mickley, L. J., and Jacob, D. J.: Correlations between fine particulate matter $\left(\mathrm{PM}_{2.5}\right)$ and meteorological variables in the United States: Implications for the sensitivity of $\mathrm{PM}_{2.5}$ to climate change, Atmos. Environ., 44, 3976-3984, doi:10.1016/j.atmosenv.2010.06.060, 2010.

Tai, A. P. K., Mickley, L. J., and Jacob, D. J.: Impact of 2000-2050 climate change on fine particulate matter $\left(\mathrm{PM}_{2.5}\right)$ air quality inferred from a multi-model analysis of meteorological modes, Atmos. Chem. Phys., 12, 11329-11337, doi:10.5194/acp-1211329-2012, 2012a. 
Tai, A. P. K., Mickley, L. J., Jacob, D. J., Leibensperger, E. M., Zhang, L., Fisher, J. A., and Pye, H. O. T.: Meteorological modes of variability for fine particulate matter $\left(\mathrm{PM}_{2.5}\right)$ air quality in the United States: implications for $\mathrm{PM}_{2.5}$ sensitivity to climate change, Atmos. Chem. Phys., 12, 3131-3145, doi:10.5194/acp12-3131-2012, 2012b.

Tsigaridis, K. and Kanakidou, M.: Secondary organic aerosol importance in the future atmosphere, Atmos. Environ., 41, 46824692, doi:10.1016/j.atmosenv.2007.03.045, 2007.

Tsimpidi, A. P., Karydis, V. A., and Pandis, S. N.: Response of inorganic fine particulate matter to emission changes of sulfur dioxide and ammonia: the eastern United States as a case study, J. Air Waste Manag. As., 57, 1489-1498, doi:10.3155/10473289.57.12.1489, 2007.

Tsimpidi, A. P., Karydis, V. A., and Pandis, S. N.: Response of fine particulate matter to emission changes of oxides of nitrogen and anthropogenic volatile organic compounds in the eastern United States, J. Air Waste Manage. As., 58, 1463-1473, doi:10.3155/1047-3289.58.11.1463, 2008.

Wang, H.-J. and Chen, H.-P.: Understanding the recent trend of haze pollution in eastern China: roles of climate change, Atmos. Chem. Phys., 16, 4205-4211, doi:10.5194/acp-16-42052016, 2016.

Wang, J., Wang, S., Jiang, J., Ding, A., Zheng, M., Zhao, B., Wong, D. C., Zhou, W., Zheng, G., Wang, L., Pleim, J. E., and Hao, J.: Impact of aerosol-meteorology interactions on fine particle pollution during China's severe haze episode in January 2013, Environ. Res. Lett., 9, 094002, doi:10.1088/1748-9326/9/9/094002, 2014.

Wang, L. T., Wei, Z., Yang, J., Zhang, Y., Zhang, F. F., Su, J., Meng, C. C., and Zhang, Q.: The 2013 severe haze over southern Hebei, China: model evaluation, source apportionment, and policy implications, Atmos. Chem. Phys., 14, 3151-3173, doi:10.5194/acp-14-3151-2014, 2014.

Wang, Z., Ding, Y., He, J., and Yu, J.: An Updating analysis of the climate change in China in recent 50 years, Acta Meteorol. Sin., 62, 228-236, doi:10.1017/CBO9781107415324.004, 2004.

Xing, J., Mathur, R., Pleim, J., Hogrefe, C., Gan, C.-M., Wong, D. C., Wei, C., and Wang, J.: Air pollution and climate response to aerosol direct radiative effects: A modeling study of decadal trends across the northern hemisphere, J. Geophys. Res.-Atmos., 120, 12221-12236, doi:10.1002/2015JD023933, 2015.
Yang, Y. Q., Wang, J. Z., Gong, S. L., Zhang, X. Y., Wang, H., Wang, Y. Q., Wang, J., Li, D., and Guo, J. P.: PLAM - a meteorological pollution index for air quality and its applications in fog-haze forecasts in North China, Atmos. Chem. Phys., 16, 1353-1364, doi:10.5194/acp-16-1353-2016, 2016.

Zaveri, R. A. and Peters, L. K.: A new lumped structure photochemical mechanism for large-scale applications, J. Geophys. Res., 104, 30387, doi:10.1029/1999JD900876, 1999.

Zaveri, R. A., Easter, R. C., Fast, J. D., and Peters, L. K.: Model for Simulating Aerosol Interactions and Chemistry (MOSAIC), J. Geophys. Res., 113, D13204, doi:10.1029/2007JD008782, 2008.

Zhang, B., Wang, Y., and Hao, J.: Simulating aerosol-radiationcloud feedbacks on meteorology and air quality over eastern China under severe haze conditionsin winter, Atmos. Chem. Phys., 15, 2387-2404, doi:10.5194/acp-15-2387-2015, 2015.

Zhang, Q., Streets, D. G., He, K., Wang, Y., Richter, A., Burrows, J. P., Uno, I., Jang, C. J., Chen, D., Yao, Z., and Lei, Y.: NO $x$ emission trends for China, 1995-2004: The view from the ground and the view from space, J. Geophys. Res.-Atmos., 112, 1995-2004, doi:10.1029/2007JD008684, 2007.

Zhang, X. Y., Wang, J. Z., Wang, Y. Q., Liu, H. L., Sun, J. Y., and Zhang, Y. M.: Changes in chemical components of aerosol particles in different haze regions in China from 2006 to 2013 and contribution of meteorological factors, Atmos. Chem. Phys., 15, 12935-12952, doi:10.5194/acp-15-12935-2015, 2015.

Zhang, Z., Zhang, X., Gong, D., Kim, S.-J., Mao, R., and Zhao, $\mathrm{X}$.: Possible influence of atmospheric circulations on winter haze pollution in the Beijing-Tianjin-Hebei region, northern China, Atmos. Chem. Phys., 16, 561-571, doi:10.5194/acp-16-5612016, 2016.

Zhao, X. J., Zhao, P. S., Xu, J., Meng,, W., Pu, W. W., Dong, F., He, D., and Shi, Q. F.: Analysis of a winter regional haze event and its formation mechanism in the North China Plain, Atmos. Chem. Phys., 13, 5685-5696, doi:10.5194/acp-13-5685-2013, 2013.

Zheng, B., Zhang, Q., Zhang, Y., He, K. B., Wang, K., Zheng, G. J., Duan, F. K., Ma, Y. L., and Kimoto, T.: Heterogeneous chemistry: a mechanism missing in current models to explain secondary inorganic aerosol formation during the January 2013 haze episode in North China, Atmos. Chem. Phys., 15, 2031-2049, doi:10.5194/acp-15-2031-2015, 2015. 